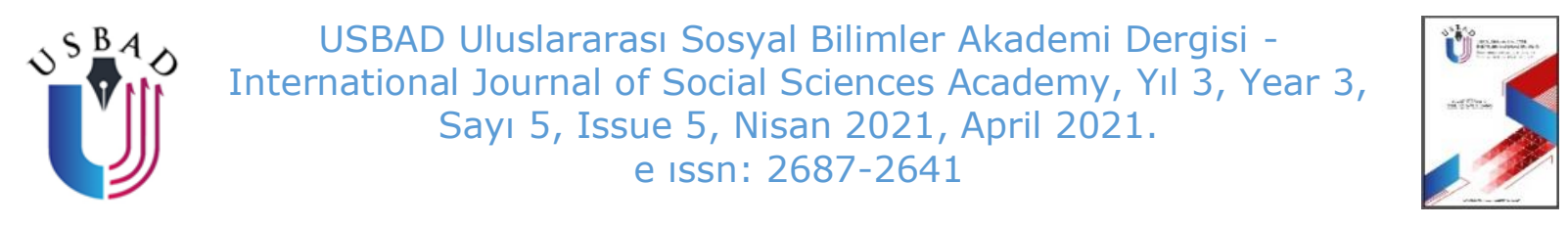

\title{
CISCO DİJİTAL HAZIRLIK ENDEKSİNDE TÜRKİYE İÇİN PERSPEKTIFLER*
}

PERSPECTIVES IN THE CISCO DIGITAL READINESS INDEX FOR TURKEY

\author{
Ali İhsan ÇELEN \\ Dr., Ordu Üniversitesi, Yönetim ve Organizasyon Bölümü, İnsan Kaynakları \\ Programı, Ünye Meslek Yüksekokulu, \\ Ordu/Türkiye.
}

PhD., Ordu University, Department of Management and Organization, Human Resource Management Programme, Ünye Vocational School,

Ordu/Turkey.

aliihsancelen@gmail.com

ORCID ID: 0000-0002-8009-3432

\section{Makale bilgisi | Article Information}

DOI: $10.47994 /$ usbad. 820248

Makale Türü / Article Type: Araştırma Makalesi / Research Article

Geliş Tarihi / Date Received: 03.11.2020

Kabul Tarihi / Date Accepted: 09.01.2021

Yayın Tarihi / Date Published: 20.04.2021

Yayın Sezonu / Pub Date Season: Nisan / April

Bu Makaleye Atıf İçin / To Cite This Article: Çelen, A. İ. (2020). Cısco

Dijital Hazırık Endeksinde Türkiye İçin Perspektifler. USBAD Uluslararası

Sosyal Bilimler Akademi Dergisi 3(5), 68-103.

Intihal: Bu makale intihal.net yazılımınca taranmıştır. İntihal tespit edilmemiştir.

Plagiarism: This article has been scanned by intihal.net. No plagiarism detected.

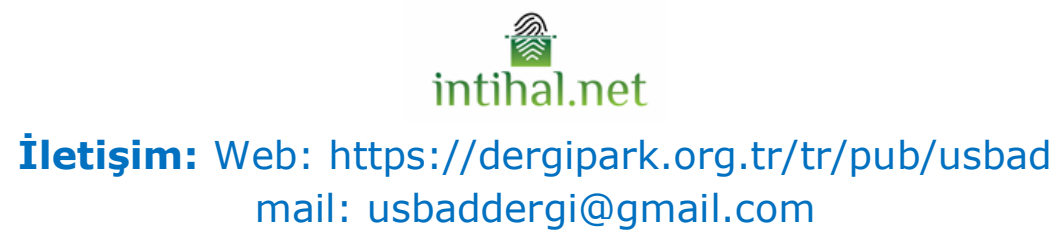

\footnotetext{
* Bu çalışma 9-10 Ekim 2020 tarihlerinde düzenlenen USVES 2020'de aynı başlık altında sunulan sözlü bildiriden türetilmiştir.
} 
Öz: Küresel dijital dönüşüm sürecine uyum, günümüz toplumlarının en temel meselesi haline gelmiştir. Ülkelerin gelişmişlik seviyelerine göre farklı düzeylerde hissedilen bu ihtiyaç özellikle gelişmekte olan ekonomiler için hayati önem taşımaktadır. Bu kapsamda ülkelere dijital dönüşüm sürecine genel hazır olma durumları ve bunu nasıl iyileştirebilecekleri konusunda rehberlik eden CISCO Hazırlık Endeksi (CHE), ülkelerin dijital hazırlık düzeyini ölçmek için geliştirilmiştir. Buna göre $\mathrm{CHE}$; temel intiyaçlar, işletme ve devlet yatırımları, iş yapma kolaylığı, beşeri sermaye, start-up çevresi, teknolojiyi benimseme ve teknoloji alt yapısı bileşenlerini dikkate almaktadır. Bu kapsamda çalışmanın amacını; küresel dijital dönüşüm sürecinde Türkiye'nin hazırlık düzeyini CISCO temel bileşenleri açısından değerlendirmek buna göre perspektifler geliştirmek oluşturmaktadır. CHE 2019 verileri ve belirlenen metrikler dikkate alınarak yapılan analizde sonuç olarak Türkiye, temel intiyaçlar açısından olumlu bir görünüm arz ederken iş kolaylığı ve beşeri sermaye konularında ortalamanın biraz üzerindedir. Ancak işletme ve devlet yatırımları, start-up çevresi, teknolojiyi benimseme ve teknoloji alt yapısı konularında ortalamanın altında bir görünüm arz etmektedir. Bu durum sağılılı bir dijital dönüşümün sağlanmasında dolayısıyla küresel rekabetin korunması ve geliştirilmesi sürecinde öncelikli politikaların ne olacağı noktasında kayda değer fikirler sunmaktadır.

Anahtar Kelimeler: CISCO Hazırlık Endeksi, Dijitalleşme, Dijital Dönüşüm, Türkiye

Abstract: Adaptation to the global digital transformation process has become Sayfa | 69 the most fundamental issue of today's societies. This need, which is felt at different levels according to the development levels of the countries, is vital importance especially for developing economies. In this context CISCO Readiness Index (CRI) guides countries on their general readiness for the digital transformation process and how they can improve it. So CRI has been developed to measure the digital readiness of countries. Accordingly, CRI takes into account; basic needs, business ve government investments, ease of doing business, human capital, start-up environment, technology adoption and technology infrastructure components.In this context, the purpose of the study; to evaluate readiness level in terms of CISCO basic components and to develop perpectives for Turkey in the global digital transformation process. The analysis was made taking into account CRI 2019 data and specified metrics. As a result of this Turkey has a positive outlook in terms of basic needs. Slightly above average in terms of ease of doing business and human capital. However Turkey is below the avarage in terms of business and government investments, start-up environment, technology adoption and technology infrastructure. This situation offers significant ideas about what the priority policies will be in the process of realized a healthy digital transformation thereby protecting and developing global competition.

Keywords: CISCO Readiness Index, Digitalization, Digital Transformation, Turkey 


\section{GİRIŞ}

Günümüz toplumlarının kalkınması ve küresel rekabet başarısı, bir anlamda dijital dönüşüme uyum sağlama becerileri ile anlam kazanmaktadır. Bu kapsamda; dijital hazırlığı tanımlamak, ölçmek, temel sorun alanlarını tespit etmek, müdahale noktalarını belirlemek amacıyla yapılan araştırmalar ve hazırlanan endeksler, dönüşümün neresinde olunduğunun tespit edilmesi ve ileriye dönük ne tür politikaların uygulanması gerektiği konusunda önemli veriler sunmaktadır. Buna göre diğer dijital hazırlık endeksleri ile kıyaslandığında daha kapsamlı ve daha anlamlı veriler sağlayan CISCO dijital hazırlık endeksi; temel ihtiyaçlar, işletme ve devlet yatırımları, iş yapma kolaylığı, beşeri sermaye, start-up çevresi, teknolojiyi benimseme ve teknolojik alt yapı bileşenleri çerçevesinde ülkelere dijital dönüşümü tanımlama, anlama, sorun alanlarını tespit etme, politika ve strateji önceliklerini belirleme konularına kaynaklık etmektedir.

Öte yandan gelişmiş ülkelere kıyasla daha çok gelişmekte olan ekonomilerin önemli bir sorunsalı haline gelen dijital dönüşüm başta üretim modelleri olmak üzere; iş ve meslek yapıları, çalışma süreleri, yönetim modelleri, ücret sistemleri, eğitim, sağlık vb. birçok konuyu çevreleyen kapsamlı ve derin bir süreci ifade etmektedir. Bu kapsamda Sayfa | 70 CISCO dijital hazırlık endeksinde ele alınan kategorilere göre Türkiye için öncelikli konular; güvenli içme suyu ve atık kontrolü, özellikle teknoloji transferi sağlayan dış yatırımların teşviki, hukukun üstünlüğünün sağlanması ve ekonomik durgunluğun aşılması, orta ve uzun vadede işgücü katılım oranlarının arttırılması, genç işsizliğinin azaltılması, işgücünün uyumlu vasıflandırılması, start-up hızlandırıcl, teknopark ve kredi risk sermayesi fon sayılarının arttırılması, yeni girişim anlamında iş yoğunluklarının arttırıması, bilgisayar kullanımı, internet erişimi ve kullanımının yaygınlaştırılması politikalarına ek olarak fiber optik ağların genişletilmesi şeklinde ön plana çıkmaktadır. Dijital dönüşüm sürecinde belirlenen konularda politikalara ve stratejilere önem ve öncelik verilmesi küresel rekabet ve toplumsal kalkınma konularında önemli avantajlar sağlayacaktır.

\section{DİJİTAL DöNÜŞÜM}

2000'li yılların başında itibaren her alanda yaşanan bilgi tabanlı dönüşüm, günümüz küresel rekabet sürecinin önemli bir argümanı haline gelmiştir. Bu durumu Kanadalı yazar ve danışman Don Tapscott Dijital Ekonomi kitabında şu cümlelerle ifade etmiştir (Tapscott, 1998: 2): 
"Biz henüz yeni bir ekonomi, yeni bir politik anlayış ve bir toplumu doğuran, Ağ Üzerindeki Akıl Çağı'nın şafak vaktindeyiz. Ağ Çağı'nda işletmeler başka bir yapıya dönüşecek, hükümetler kendilerini yenileyecek ve bireyler kendi kendilerini yeniden keşfedebileceklerdir. Tüm bunlar ise yeni bilgi teknolojisi ile gerçekleşecek. Gelecek, sayısız yeni fırsat olduğu kadar yeni tehlikeleri de içeriyor. Sosyal sınıflar arasında ayrımların giderek artma, özel hayatın ve diğer hakların benzeri görülmedik bir şekilde ihlali, sosyal çatışmalar ve yapısal bir işsizlik sorunu, geleceğin karanlık yanları... Ama gelecek, toplum ve iş dünyası olarak bizim ne yaptığımıza, yani kararlarımıza ve davranış biçimlerimize göre şekillenecektir."

Bu kapsamda ağ üzerindeki akıl çağı şeklinde tanımlanan sürecin; işletmeler başta olmak üzere hükümet yapıları ve bireyler üzerinde etkili olacağı vurgulanmıştır. Aynı şekilde bu sürecin önemli fırsatlar sunduğu kadar yeni tehlikeleri de beraberinde getireceğine dikkat çekilmektedir. Özellikle birey ve toplumların ne yaptığı, kararlarının ne olduğu ve davranış biçimlerinin nasıl şekillendiği konusu ile ilişkilendirilen bu dönüşümün, birey veya toplumun uyum yeteneği ile örtüştüğü belirtilmektedir.

Buna göre özellikle 2000'li yılların başından itibaren her alanda kendini hissettiren bilgi tabanlı dönüşüm, günümüz rekabet sürecinin önemli bir argümanı haline gelmiştir. Nitelikli işgücü eksikliği, yaşlanan toplum, çalışma dönemi ve sonrası emeklilik, kaynak verimi ve temiz kentsel üretim, ürün parti boyutu-kitlesel özelleştirmeler, düşük hacimli daha karmaşık fabrika, ürün değişkenliğini arttırma, daha kısa ürün yaşam döngüsü, dinamik değer zinciri ağları, maliyeti azaltma baskısı vb. birçok sosyo-ekonomik gelişmeleri derinden etkileyen bu dönüşüm süreci (DFKI, 2016) Endüstri 4.0 kavramı ile tanımlanmakta ve günümüz üretim, tüketim ve yönetim ilişkilerinin açıklanmasında büyük önem taşımaktadır (Şekil 1).

Şekil 1: Endüstri Devrimleri 


\begin{tabular}{|c|c|c|c|}
\hline & & & $\begin{array}{l}\text { IV. ENDÜSTRİ } \\
\text { DEVRIMİ }\end{array}$ \\
\hline \multirow{2}{*}{$\begin{array}{l}\text { İlk } \\
\text { mekanik } \\
\text { dokuma } \\
\text { tezgâhı } \\
1784\end{array}$} & \multirow[b]{2}{*}{$\begin{array}{l}\text { II. ENDÜSTRİ } \\
\text { DEVRIMII }\end{array}$} & \multirow{3}{*}{$\begin{array}{c}\text { III. ENDÜSTRI } \\
\text { DEVRIMI }\end{array}$} & \multirow{2}{*}{$\begin{array}{c}\text { Siber-Fiziksel } \\
\text { üretim } \\
\text { sistemlerine } \\
\text { dayalı dönüşüm } \\
\text { ile }\end{array}$} \\
\hline & & & \\
\hline $\begin{array}{l}\text { I. ENDÜSTRİ } \\
\text { DEVRIMİ }\end{array}$ & \multirow{2}{*}{$\begin{array}{l}\text { Elektrik enerjisi } \\
\text { ile işgücünün } \\
\text { bölünmesine } \\
\text { dayalı seri } \\
\text { üretime geçilmesi } \\
\text { ile } \\
\text { ENDüsTRí } \mathbf{2 . 0}\end{array}$} & & \\
\hline $\begin{array}{l}\text { Su ve buhar ile } \\
\text { çalışan mekanik } \\
\text { üretim tesislerinin } \\
\text { tanıtılması ile } \\
\text { ENDÜSTRİ } 1.0\end{array}$ & & ENDÜSTRİ $\mathbf{3 . 0}$ & ENDÜSTRİ 4.0 \\
\hline & \multirow{2}{*}{ 20. yy başı } & & \\
\hline 18. yy sonu & & yılların başlamas & Günümüz \\
\hline
\end{tabular}

(DFKI, 2016)

18. yüzyılın son çeyreğinde ilk mekanik üretim tesislerinin

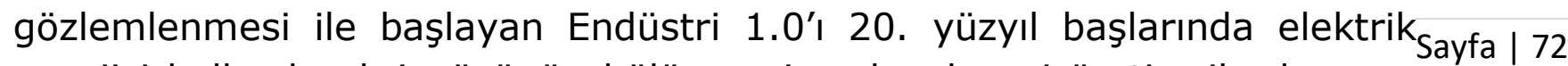
enerjisi kullanılarak işgücünün bölünmesine dayalı seri üretim ile devreye giren Endüstri 2.0 takip etmiştir. 1970'li yıllar ile yeni bir kırılma noktası yaşayan üretim sistemleri, daha fazla otomatikleştirme amaçlı elektrik ve bilgi teknolojilerinin tanıtılmasıyla şekillenmiş ve Endüstri 3.0 devreye girmiştir. Dijital dönüşümün ana faktörü konumunda olan internetin 90'lı yılların ortalarından itibaren yaygınlaşmaya başlaması, bilgi tabanlı dönüşümü gündeme getirmiştir. Dolayısıyla günümüzde halen etkisi devam eden siber fiziksel üretim sistemlerine dayalı Endüstri 4.0 yaşanmaktadır.

Öte yandan dijitalleşme sürecinin en önemli göstergelerinden biri de dijital nüfus verileridir. Temmuz 2020 itibariyle 4,57 milyara ulaşan aktif internet kullanıcısı, 4,17 milyara ulaşan sadece mobil internet kullanıcısı 3,96 milyara ulaşan aktif sosyal medya kullanıcısı ve 3,91 milyara ulaşan aktif mobil sosyal medya kullanıcı sayısının olması küresel çapta dijitalleşmenin önemli bir boyutunu göstermektedir (Grafik 1). Diğer bir ifade ile ikili kodlama sistemine göre düzenlenmiş verileri depolayan veya ileten en önemli teknolojilerden biri olarak tanımlanan internet, bu dönüşüm sürecinde küreselleşme dâhil pek çok konu üzerinde derin etkiler bırakmış ve dijitalleşmenin temel lokomotifi haline gelmiştir (Ritzer, 2011). 
Grafik 1: Küresel Dijital Nüfus (Temmuz 2020)

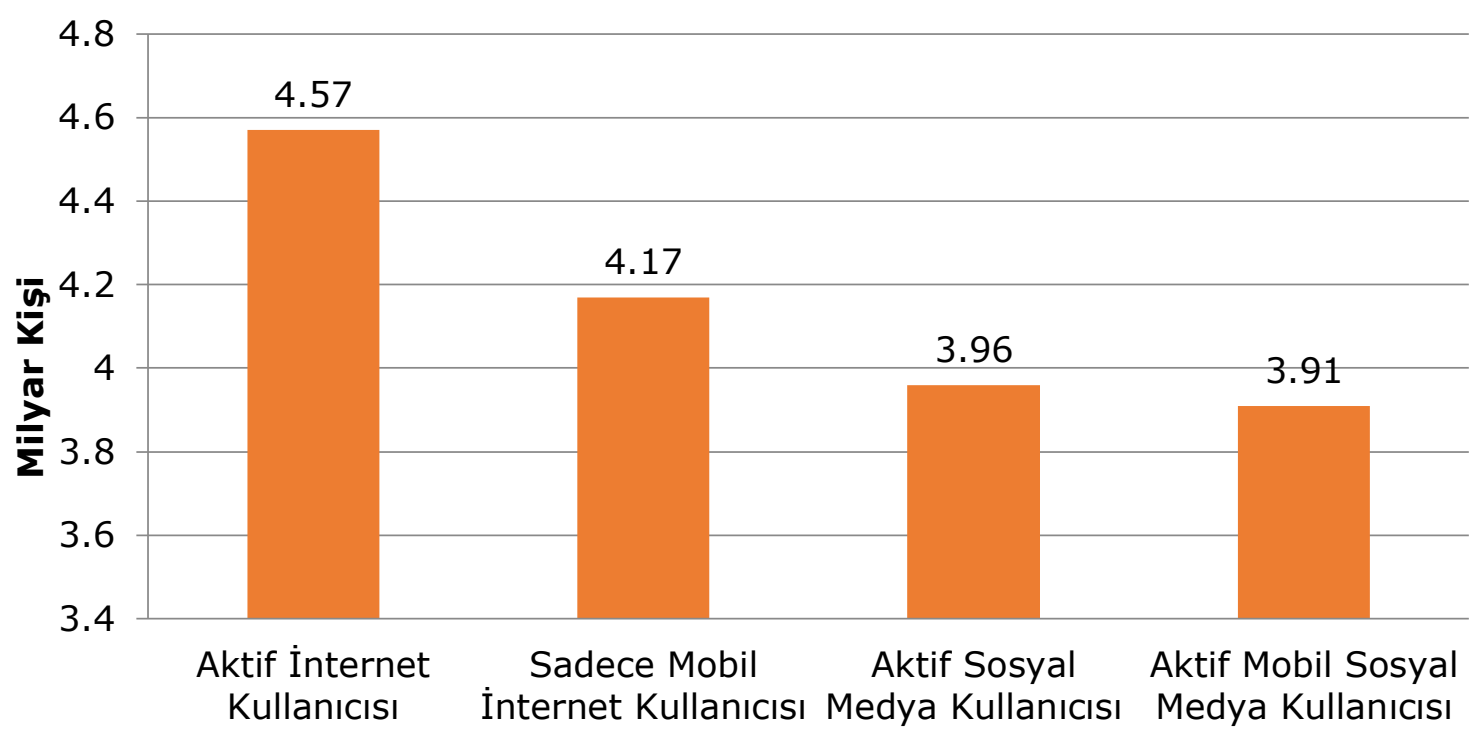

(Statista, 2020)

Aynı şekilde 2,3 milyar kişi ile en fazla Asya kıtasında bulunan kullanıc sayısını, 727 milyon kişi ile Avrupa, 522 milyon kişi ile Afrika, 453 milyon kişi ile Latin Amerika/Karayipler, 327 milyon kişi ile Kuzey Amerika, 175 milyon kişi ile Orta Doğu ve 29 milyon kişi ile Okyanusya/Avusturalya bölgesi takip etmektedir (Grafik 2).

Grafik 2: Kıtalar Bazında İnternet Kullanıcısı Sayısı (Mart 2020)

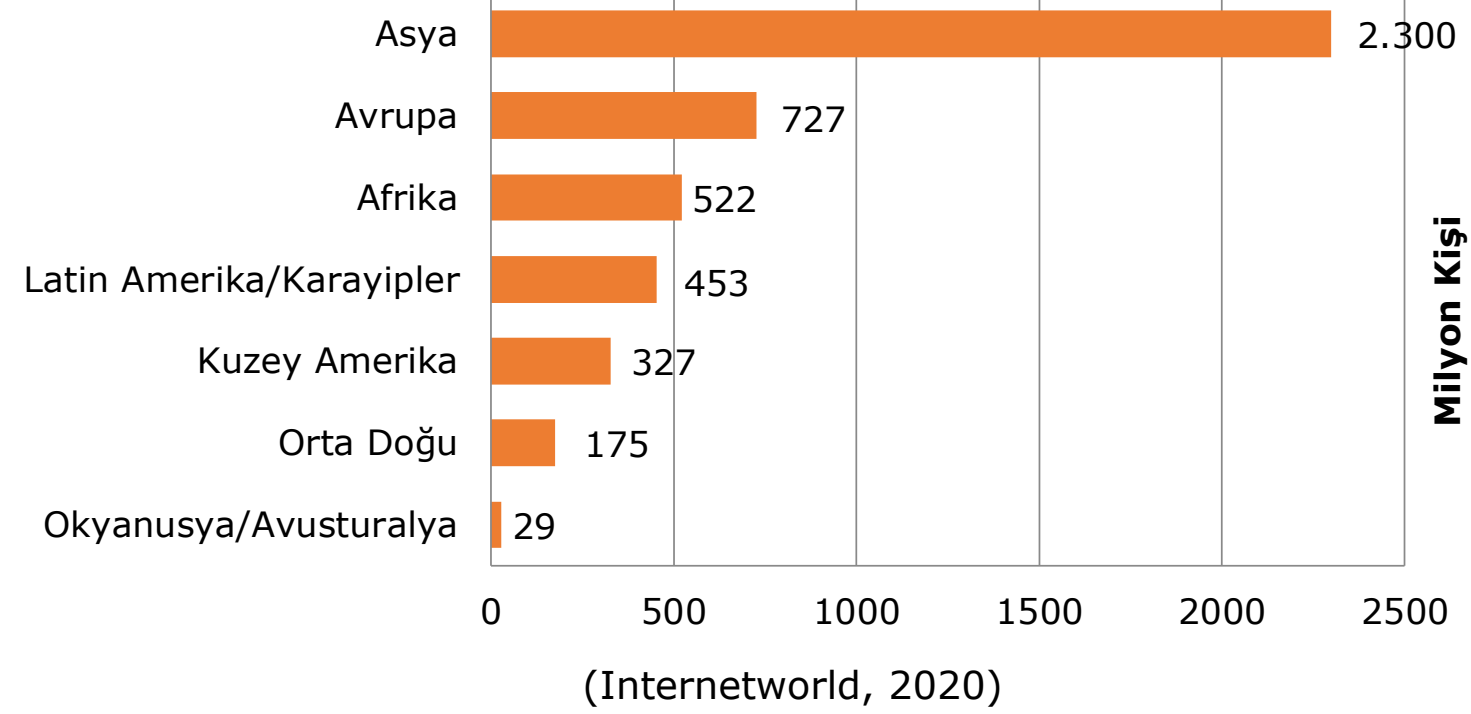

Mart 2020 itibariyle dünya nüfusunun \%58,7'si internete girebilir hale gelirken bölgeler bazında bu dağılım Kuzey Amerika \%94,6 Avrupa $\% 87,2$ Latin Amerika/Karayipler \%70,5 Orta Doğu \%69,2 Asya \%53,6 Afrika \%39,3 şeklinde gerçekleşmiştir (İnternetworld, 2020). Bu kapsamda özellikle güneydeki ülkelerin; internete ulaşmalarını imkân sağlayan bilgisayarı çalıştıracak elektrikten yoksun olmaları, yetersiz dijital 
teknolojilere sahip olmaları, internet hizmeti sağlayan ana bilgisayarların çoğunun kuzeyde bulunması, alt yapı yokluğu ve bu bölgelerdeki dijital teknolojilerin maliyeti için yeterli gelire sahip olamamaları dolayısıyla internete bağlanmanın caydırıcı pahalııı̆ı, internette web sayfalarının çoğunluğunun (\%80'den fazlasının) İngilizce olması vb. (Ritzer, 2011: 423-424) sorunlarla karşılaşmaları dijital dönüşüm sürecinde kuzeydeki ülkeleri güneydeki ülkelerden daha avantajlı kılmıştır. Diğer bir ifade ile kuzeydeki ülkelerin bahsedilen konular açısından daha fazla avantaja sahip olmaları dijital dönüşüm sürecine de yansımıştır. Toplumsal kalkınma ve küresel rekabet başta olmak üzere birçok alanda hissedilen bu durum dijital dönüşümü özellikle gelişmekte olan ülkeler için öncelikli konu haline getirmiştir.

\section{DİJİTAL DÖNÜŞÜMDE CISCO ENDEKSİ VE METODOLOJİSİ}

Kaliforniya merkezli Amerikalı çok uluslu bir ağ teknolojileri şirketi (2019 yılı itibariyle 51,90 milyar dolar geliri ve 70 bin civarında çalışanı) olan CISCO Systems; ağ donanımı, yazılımı, telekomünikasyon ekipmanı ve diğer yüksek teknoloji ürünleri ve hizmetleri geliştirmekte, üretmekte ve satmaktadır. Buna göre dijital dönüşüm sürecinin merkezinde bulunan CISCO Systems, hazırlamış olduğu çok yönlü dijital hazırlık endeksi ile ülkelere önemli veriler sunmaktadır. Uygulamada IT Digital, EY Digital, Sayfa | 74 IMD World Digital gibi birçok dijital hazırlık endeksi ile karşılaşmak mümkündür ancak farklı olarak CISCO; diğer dijital hazırlık endekslerine göre daha kapsamlı, daha anlamlı ve sürdürülebilir kalkınma kapsamında veriler sunmaktadır. Buna göre CISCO; dijital hazırlığı tanımlamak, ülkelerin dijital hazırlığını ölçmek ve ülkelerin dijital hazırlık süreçlerinde yükselmelerine yardımcı olabilecek temel müdahaleleri keşfetmek için tüm ülke ve bölgelerde uygulanabilir bir model sunmaktadır. Belirlenen modelde teknoloji faktörü; dijital hazırlık için kritik ve ana faktör kabul edilmektedir. Ancak CISCO, dijital hazırlığı tanımlamada sadece teknoloji faktörünü dikkate almayarak diğer endekslerine göre daha bütünsel bir yaklaşım sunmaktadır. Bu kapsamda CISCO'nun dikkate aldığı bileşenler şu şekildedir:

- Temel intiyaçlar

- İşletme ve devlet yatırımları

- İş yapma kolaylığı

- Beşeri sermaye

- Start-up çevresi

- Teknolojiyi benimseme

- Teknolojik alt yapı 
Bir nüfusun hayatta kalması ve gelişmesini gösteren temel ihtiyaçlar göstergesi, yenilik ve teknoloji alanında yapılan özel ve kamu yatırımlarını gösteren işletme ve devlet yatırımları göstergesi, iş sürekliliğini desteklemek için gereken temel alt yapı ve politikaları gösteren iş yapma kolaylığı göstergesi, dijital yeniliği desteklemek, inşa etmek ve sürdürmek için gerekli olan vasıflı işgücünü gösteren beşeri sermaye göstergesi, bir topluluk içinde yeniliği teşvik eden başlangıç ortamını gösteren start-up çevresi göstergesi, dijital ürün ve talepleri gösteren teknolojiyi benimseme göstergesi, dijital etkinlikleri ve bağlantılı tüketicileri mümkün kılan altyapıyı gösteren teknolojik alt yapı göstergesi temel alınan bileşenlerdir. Belirlenen 7 temel bileşenden oluşan bütünsel model 0-25 arasında değişen puanlamalarla 141 ülkeye uygulanmıştır. Her ülke için Dünya Bankası, Dünya Ekonomik Forumu, Birleşmiş Milletler, Amerikan Girişimcilik Merkezi, Miras Vakfı, Uluslararası Çalışma Örgütü, Uluslararası Para Fonu, Uluslararası Telekomünikasyon vb. birçok saygın kurumlardan alınan standartlaştırılmış verilere göre puanlamalar yapılmıştır. Ayrıca belirlenen ana bileşenler çerçevesinde alt kategoriler belirlenerek ana bileşenlerin hem temsil kabiliyeti arttırılmış hem de dijital hazırlık sürecine daha kapsamlı ve gerçekçi bir perspektif sunulmuştur. Bu kapsamda belirlenen ana bileşenlere atanan alt kategoriler şu şekildedir:

1. Temel İhtiyaçlar

- Yaşam beklentisi

- Ölüm oranı (5 yaş altı)

- Güvenli içme suyu hizmetlerini kullanan nüfus

- Elektriğe erişim

2. İşletme ve Devlet Yatırımları

- Doğrudan yabancı yatırım

- Araştırma ve geliştirme giderleri

- Yatırım özgürlüğü

3. İş Yapma Kolaylığı

- İş yapma kolaylığı endeksi

- Yasal düzenlemeler

- Lojistik performans endeksi

- Elektriğe ulaşım süresi

4. İnsan Sermayesi (Beşeri Sermaye)

- İşgücü katılım oranı

- Yetişkin okuryazarlık oranı

- Eğitim endeksi

- Uyumlaştırılmış test puanı

5. Start-Up Çevresi 
- Yeni iş yoğunluğu

- Verilen patentler ve tescilli ticari markalar

- Risk sermayesi yatırımı ve kullanılabilirliği

6. Teknolojiyi Benimseme

- Mobil cihaz penetrasyonu

- İnternet kullanımı

- Bulut hizmetleri

7. Teknolojik Alt Yapı

- Mobil geniş bant abonelikleri

- Sabit geniş bant abonelikleri

- Güvenli internet sunumları

- Ev internet erişimi

\section{CISCO ENDEKSİ TEMEL BİLEŞENLERİ VE TÜRKİYE}

\subsection{Temel İhtiyaçlar}

CISCO dijital hazırlık endeksinde temel intiyaçlar bileşeni;

- Yaşam beklentisi,

- Ölüm oranı (5 yaş altı),

- Güvenli içme suyu hizmetlerini kullanan nüfus,

- Elektriğe erişim,

kategorilerinde değerlendirilmiştir. Endekste Japonya, Singapur, İspanya, İsviçre ve İzlanda ülkeleri ilk sıralarda yer alırken Türkiye 4 üzerinden yapılan puanlamada 3,66 puan ile 51. sırada iyi sayılabilecek bir kademede bulunmaktadır (Tablo 1).

Tablo 1: Temel İhtiyaçlar Bileşeninde Türkiye

\begin{tabular}{ccc}
\hline Sıra & Ülke & Puan (4 üzerinden) \\
\hline 1 & Japonya & 3,98 \\
2 & Singapur & 3,97 \\
3 & İspanya & 3.97 \\
4 & İsviçre & 3,96 \\
5 & İzlanda & 3,96 \\
$\ldots$. & $\ldots$ & $\ldots$ \\
49 & Kuveyt & 3,66 \\
50 & Bulgaristan & 3,66 \\
\hline 51 & Türkiye & $\mathbf{3}, 66$ \\
52 & Litvanya & 3,65 \\
53 & Tayland & 3,65 \\
\hline 54 & Çin & 3,65 \\
$\ldots$ & $\ldots$ & $\ldots$ \\
\hline & Dünya Ortalaması (141 Ülke) & $\mathbf{3 , 0 9}$ \\
\hline
\end{tabular}

(CISCO, 2019) 
Temel ihtiyaçlar bileşenine göre: (Worldbank, 2020)

- Türkiye'de 2000 'li yılların başında 70 yıl olan ortalama yaşam beklentisi 2017 yılı itibariyle 77,16 yıla yükselmiştir.

- 2008 yılında (1000 canlı doğumda) 17,1 olan bebek ölümleri 2018 yılı itibariyle 9,1'e düşmüştür.

- 2018 yılı itibariyle elektriğe erişim nüfusun \%100'üdür.

- Güvenli içme suyu konusunda ise; yılda kişi başına düşen $1.519 \mathrm{~m}^{3}$ lük su miktarı ile "su sıkıntısı çeken bir ülke" olarak tanımlanmaktadır. En önemli sorun 2030 yılına kadar 100 milyona ulaşacağı tahmin edilen nüfus miktarına karşılık kişi başına düşen su miktarının $1.120 \mathrm{~m}^{3}$ e düşeceği beklentisi, Türkiye'yi "su fakiri olma yolunda ilerlediği şeklinde yorumlanmaktadır. Bu durum gıda güvenliği, enerji güvencesi, ekonomik büyüme, iklim değişikliği ile mücadele, biyo-çeşitliliğin korunması vs. konular açısından büyük önem taşımaktadır. Aynı şekilde tatlı su kaynaklarının; kentsel atık sularının arıtılmadan ya da kısmen arıtılarak yüzey sularına deşarj edilmesi, kanalizasyon ve katı atık yığınlarının yeraltı sularını kirletmesi, tarım ilaçları, kimyasal gübreler, ormansızlaşma, yetersiz ve yanlış tarımsal uygulamalar vb. sorunlar bu kapsamda ön plana çıkmaktadır.

\section{2. İşletme ve Devlet Yatırımları}

CISCO dijital hazırlık endeksinde işletme ve devlet yatırımları bileşeni;

- Doğrudan yabancı yatırım (DYY),

- Araştırma ve geliştirme giderleri (ar-ge),

- Yatırım özgürlüğü

kategorileriyle birlikte ele alınmıştır. Bu bileşende Singapur, İsviçre, Hollanda, Lüksemburg ve İsveç ilk sıralarda yer alırken Türkiye 3 üzerinden yapılan puanlamada 1,37 puan ile 46. sırada yer almaktadır (Tablo 2).

Tablo 2: İşletme ve Devlet Yatırımları Bileşeninde Türkiye

\begin{tabular}{ccc}
\hline Sıra & Ülke & Puan (3 üzerinden) \\
\hline 1 & Singapur & 2,71 \\
2 & İsviçre & 2,48 \\
3 & Hollanda & 2,48 \\
4 & Lüksemburg & 2,41 \\
5 & İsveç & 2,31 \\
$\ldots$ & $\ldots$ & $\ldots$ \\
\hline
\end{tabular}




\begin{tabular}{ccc}
\hline 44 & Meksika & 1,37 \\
45 & Karadağ & 1,37 \\
46 & Türkiye & $\mathbf{1 , 3 7}$ \\
47 & Panama & 1,36 \\
48 & Malezya & 1,35 \\
49 & Birleşik Arap Emirlikleri & 1,35 \\
$\ldots$ & $\ldots$ & $\ldots$ \\
\hline & Dünya Ortalaması (141 Ülke) & $\mathbf{1 , 3 1}$ \\
\hline
\end{tabular}

(CISCO, 2019)

Tabloya göre Meksika, Karadağ, Panama, Malezya, Birleşik Arap Emirlikleri grubunda yer alan Türkiye, dünya ortalaması düzeyinde bir görünüm arz etmektedir. Bu tablonun ortaya çıkmasında etkili olan en önemli faktörlerden birini, özellikle önemli bir teknoloji transferi yöntemi olarak kullanılan DDY'ler oluşturmaktadır (Grafik 3).

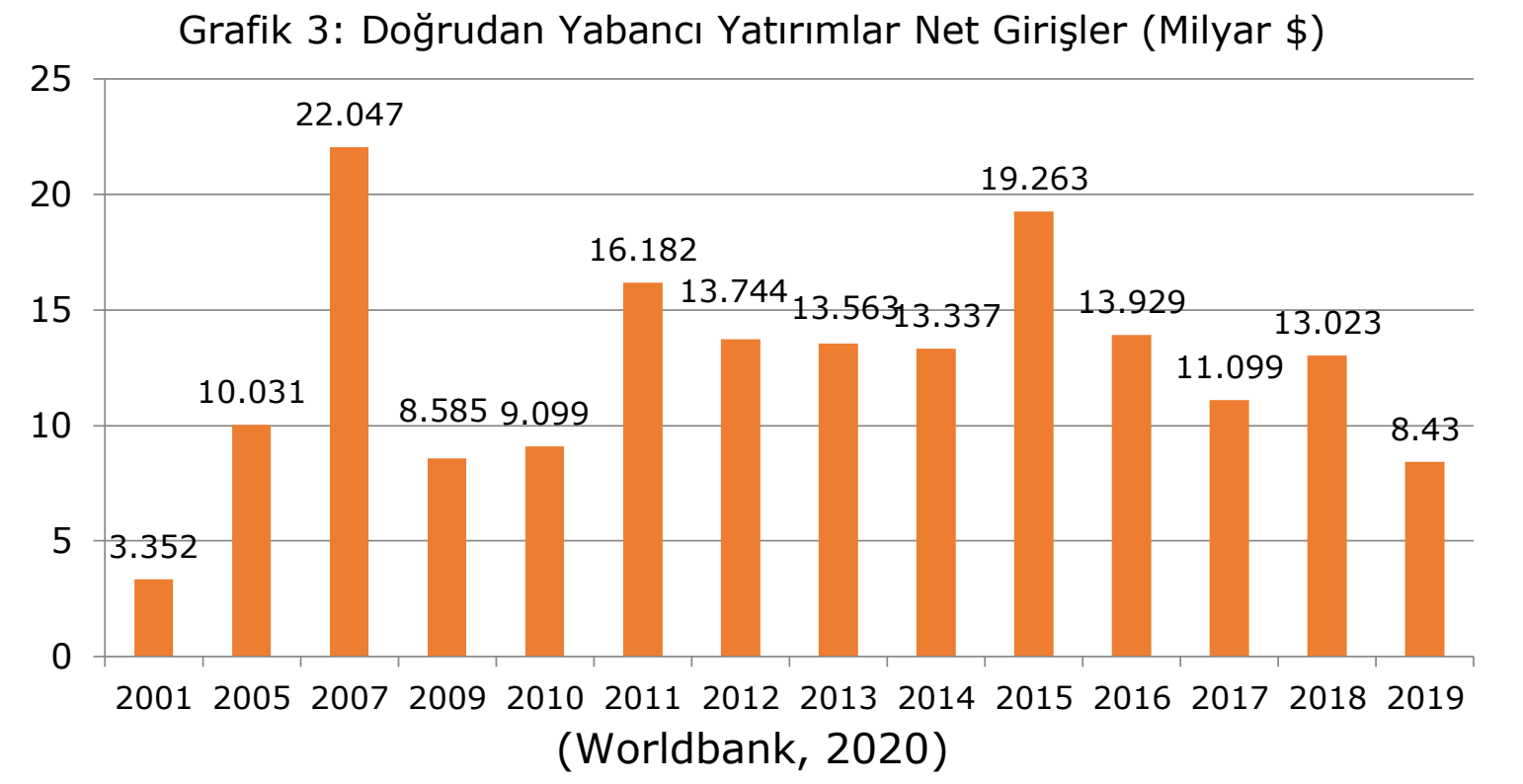

Sayfa | 78

Grafik 3'e göre 2007 yılında 22,047 milyar \$'a kadar yükselen DDY net girişler takip eden yıllarda dalgalı bir seyir izlemiş ve 2019 yılında, kriz sonrası dönemin en düşük seviyesini görmüştür. Diğer bir ifade ile 2019 yılında DDY net girişler \%35 daralmıştır. Bu durum DDY'nin Türkiye'de önemli bir teknoloji transferi yöntemi olarak kullanılması (Tiryakioğlu, 2014), (Yıldırım, 2019) noktasında büyük önem arz etmektedir. Diğer bir ifade ile dijital dönüşüm sürecinde DDY net girişlerinin daralması, gerekli olan alt yapının kurulması ve teknoloji transferinin sağlanması noktasında negatif etkiler oluşturma potansiyeline sahiptir. Öte yandan işletme ve devlet yatırımları bileşeninde bir diğer önemli kategoriyi ise ar-ge'ye ayrılan bütçe oluşturmaktadır (Grafik 4). 
Grafik 4: OECD Ülkelerinde Ar-ge Bütçesi

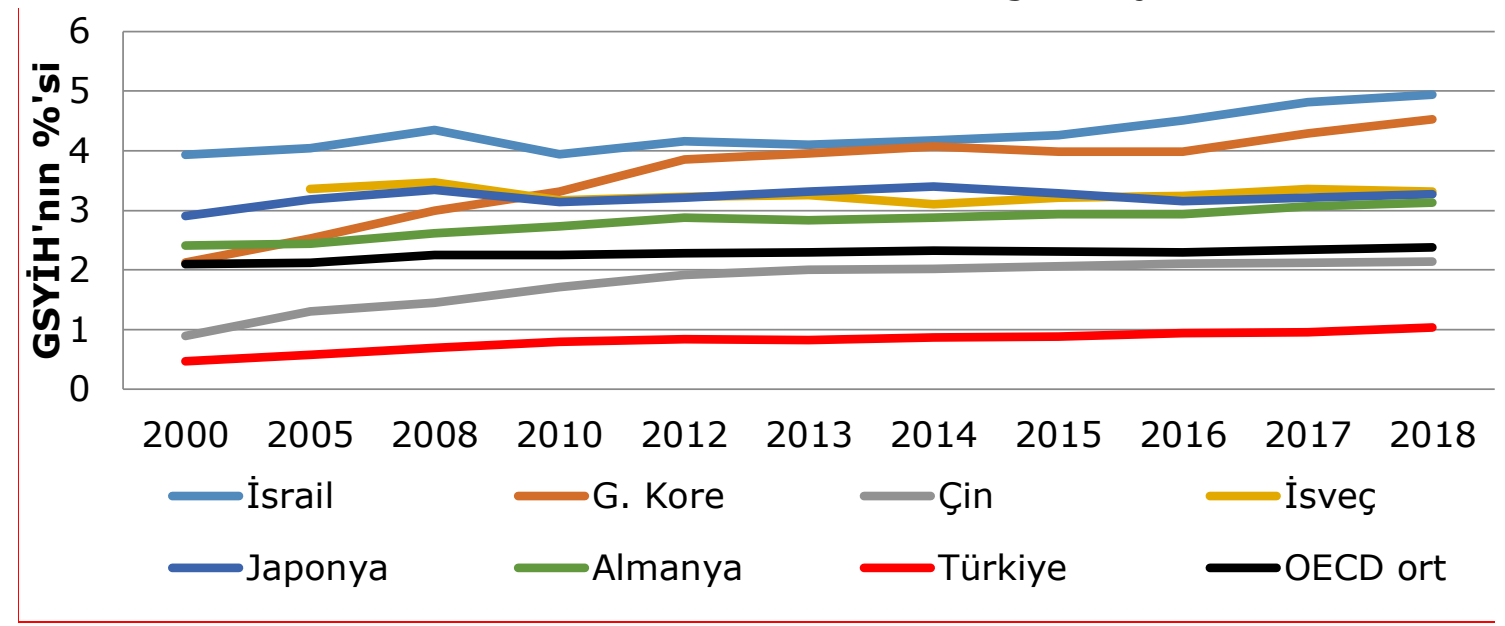

(Oecd, 2020)

Grafik 4'e göre İsrail GSYİH'nın \%4,941'ini ar-ge bütçesi olarak ayırarak OECD sıralamasında ilk sırada yer almaktadır. Bunu; Güney Kore $\% 4,528$, Japonya $\% 3,275$, İsveç $\% 3,321$, Almanya $\% 3,13$, Çin $\% 2,141$ takip etmektedir. Türkiye'de ise bu oran \%1,035 olarak gerçekleşmiştir. OECD ortalamasının \%2,379 olduğu dikkate alındığında Türkiye'de arge'ye ayrılan payın oldukça düşük olduğu görülmektedir. Ayrıca CISCO dijital hazırlık endeksi genel sıralamasında Ar-ge'ye en fazla bütçe ayıran ülkelerden İsveç 7. sırada, G. Kore 8. sırada, Almanya 14. sırada, Japonya Sayfa | 79 16. sırada ve İsrail 21. sırdadır. OECD ortalamasının altında kalan Çin 54. sırada iken Türkiye 59. sırada yer almaktadır.

Öte yandan dünya çapında ekonomik özgürlüğü ve serbest piyasaların etkisini gösteren ekonomik özgürlük endeksi (Index of economic freedom) yine dijital dönüşüm sürecinde dikkate alınan bir diğer işletme ve devlet yatırımları kategorisini oluşturmaktadır. Buna göre 2020 yılı itibariyle 71 . sırada (64,4 puan bazında) Türkiye ılımlı özgür kategorisinde değerlendirilmektedir. Listenin başında ise Singapur $(89,4)$, Hong Kong $(89,1)$, Yeni Zelanda $(84,1)$, Avustralya $(82,6)$, İsviçre $(82)$ ve İrlanda $(80,9)$ yer almaktadır. Bu kapsamda raporda Türkiye ile ilgili sorun alanları şu şekilde belirtilmektedir (Heritage, 2020):

- Avrupa ülkeleri ile kıyaslandığında genel puan bölge ortalamasının altındadır.

- 2018 yılında bir borç ve para krizi ile birlikte ekonomik durgunluk başlamıştır.

- Kamu maliyesinin, iyi sermayeli bankaların, dinamik ve çeşitlendirilmiş özel sektörün ekonomiye sağlamlık kattığı belirtilmektedir. 
- Acil olarak yargının etkinliği ve yolsuzlukla mücadelenin güçlendirilmesi konuları dikkat çekilmektedir.

- Özellikle 2016 yılı darbe girişimi önemli bir negatif etki olarak görülmektedir. Ayrıca vergi yükünün arttığı ve parasal özgürlüğün kısıtlandığı bilgilerine de yer verilmektedir.

Bu kapsamda özellikle teknoloji transferinde önemli rol oynayan yabancı yatırımların özellikle son beş yılda azalan bir seyir izlemesi, arge'ye ayrılan bütçenin OECD ortalamasının oldukça gerisinde kalması ve yatırım özgürlüğünde dikkat çekilen; ekonomik durgunluk, yargının bağımsızlığı sorunu, yolsuzlukla mücadele, vergi yükünün arttırılması ve kısıtlı parasal özgürlük konuları dijital hazırlık sürecinde önemli sorun alanlarını oluşturmaktadır

\section{3. İş Yapma Kolaylığı}

Dijital hazırlık endeksinde dikkate alınan bir diğer bileşen ise iş yapma kolaylığıdır. Bu bileşenin ölçülmesinde geliştirilen dört temel kategori şu şekildedir:

- İş yapma kolaylığı endeksi,

- Yasal düzenlemeler (hukukun üstünlüğü),

- Lojistik performans endeksi-Alt yapı derecelendirmeleri,

- Elektriğe ulaşım süresi,

Buna göre iş yapma kolaylığı bileşeninde yer alan iş yapma kolaylığı endeksi, yasal düzenlemeler (hukukun üstünlüğü), lojistik performans-alt yapı derecelendirme ve elektriğe ulaşım kategorilerine göre Türkiye; 4 üzerinden yapılan puanlamada 2,67 puan ile 45 . sırada yer almaktadır (Tablo 3). 
Tablo 3: İş Yapma Kolaylığı Bileşeninde Türkiye

\begin{tabular}{ccc}
\hline Sıra & Ülke & Puan (4 üzerinden) \\
\hline 1 & Danimarka & 3,76 \\
2 & Almanya & 3,76 \\
3 & İsveç & 3,72 \\
4 & Singapur & 3,69 \\
5 & Avusturya & 3,68 \\
$\ldots$ & $\ldots$ & $\ldots$ \\
43 & Kosta Rika & 2,70 \\
44 & Panama & 2,68 \\
45 & Türkiye & $\mathbf{2 , 6 7}$ \\
46 & Umman & 2,65 \\
47 & Vietnam & 2,64 \\
\hline 48 & Slovakya & 2,64 \\
$\ldots$ & $\ldots$ & $\ldots$ \\
\hline & Dünya Ortalaması (141 Ülke) & $\mathbf{2 , 4 4}$ \\
\hline
\end{tabular}

(CISCO, 2019)

Aynı şekilde Danimarka, Almanya, İsveç, Singapur ve Avustralya'nın ilk sıralarda yer aldığı endekste Türkiye; Kosta Rika, Panama, Umman, Vietnam ülke grubunda yer alarak ortalamanın biraz üstünde bir görünüm arz etmektedir. Buna bağlı olarak belirlenen kategoriler çerçevesinde Türkiye ile ilgili şu tespitlere yer verilmektedir:

- Dünya bankası tarafından; aralarında iş kurma, üretim izni, elektrik enerjisi, kredi sağlama, mülkiyet, yatırımcılı̆ın korunması, vergi ödeme, sınırlar arası ticaret, güçlendirilmiş sözleşmeler, sorun çözme, işgücü, hükümet ile anlaşma vb. kıstasların yer aldığı iş yapma kolaylığı göstergesinde 190 ülkeden Türkiye 76,8 puan ile 33. sırada yer almaktadır. Listenin başında ise Yeni Zelanda $(86,8)$, Singapur $(86,2)$, Hong Kong $(85,3)$, Danimarka $(85,3)$, Güney Kore (84) yer almaktadır (The World Bank , 2020 ).

- Hükümet yetkilerindeki kısıtlamalar, yolsuzluğun olmaması, şeffaflık, temel haklar, düzen ve güvenlik, düzenleyici uygulamalar, medeni kanun ve ceza kanunu vb. faktörlerin yer aldığı hukukun üstünlüğü kategorisinde 0-1 puan aralığında Türkiye, 0,42 puanla 109. sırada yer almaktadır. Bu puan ile Türkiye, yapılan sınıflandırmada en düşük kategori olarak gösterilen $(0,40$ 'ın altı) gruba oldukça yakın gösterilmektedir (World Justice Project, 2019).

- Gümrük, alt yapı, uluslararası gönderiler, lojistik yeterliliği, izleme ve izlenme, zaman konularının değerlendirildiği Lojistik Performans İndeksinde Türkiye, 3,15 puan ile 47. sırada yer almaktadır. Listenin başında ise Almanya (4,20), İsveç $(4,05)$, Belçika $(4,04)$, Avusturya 
$(4,03)$, Japonya $(4,30)$ ve Hollanda $(4,02)$ yer almaktadır (Worldbank, 2018).

- Elektriğe erişim, iş yapma kolaylığının önemli bir bileşeni ve dijital dönüşümün olmazsa olmazlarından biri olarak görülmektedir. Bu kapsamda Türkiye uyumlu ekonomiler arasında gösterilmektedir. Bu durum özellikle yeni yatırımlarda elektriğe ulaşım sürecinin her geçen yıl azalmasından kaynaklanmaktadır. Nitekim 2014 yılında ortalama 62 gün olan bu süre 2019 yılı itibariyle 34 güne kadar düşürülmüştür (Worldbank, 2019).

Buna göre iş yapma kolaylığı kapsamında; iş kurma, üretim izni, yeterli elektrik enerjisi, kredi sağlama, mülkiyet, yatırımcılığın korunması, ödeme, sınırlar arası düzenlemeler, hükümet ile anlaşma, gümrük, lojistik altyapısı, uluslararası gönderiler, izleme ve izlenme, zaman, elektriğe erişim konuları iyi derecede bir görünüm arz ederken kısıtlamalar, yolsuzluk, şeffaflık, temel hakların kullanılması, düzen ve güvenlik konuları temel sorun alanlarını oluşturmaktadır.

\subsection{Beşeri Sermaye}

Dijital dönüşüm sürecinin önemli yönlerinden birini de beşeri sermaye konusu oluşturmaktadır. Özellikle bilgi toplumlarında önem Sayfa| 82 kazanan fikir emeği ile anlam kazanan beşeri sermayenin rolü giderek artmaktadır. Bu kapsamda CISCO beşeri sermaye bileşenini ayrıca değerlendirmiş ve buna bağlı olarak dört temel alt kategori belirlemiştir:

- İşgücüne katılım oranı

- Yetişkin okuryazarlık oranı

- Eğitim endeksi

- Uyumlaştırılmış test puanı

Buna göre işgücüne katılım oranı, yetişkin okuryazarlık oranı, eğitim endeksi ve uyumlaştırılmış test puanı kategorilerinden oluşan beşeri sermaye bileşeninde Singapur, İzlanda, Yeni Zelanda, İsviçre ve Kazakistan ilk sıralarda yer alırken Türkiye 4 üzerinden yapılan puanlamada 2,45 puan ile ortalamaya çok yakın bir görünüm arz etmektedir (Tablo 4). 
Tablo 4: Beşeri Sermaye Bileşeninde Türkiye

\begin{tabular}{ccc}
\hline Sıra & Ülke & Puan (4 üzerinden) \\
\hline 1 & Singapur & 3,43 \\
2 & İzlanda & 3,43 \\
3 & Yeni Zelanda & 3,37 \\
4 & İsviçre & 3,34 \\
5 & Kazakistan & 3,33 \\
$\ldots$ & $\ldots$ & $\ldots$ \\
77 & Paraguay & 2,46 \\
78 & Suudi Arabistan & 2,46 \\
79 & Türkiye & $\mathbf{2 , 4 5}$ \\
80 & Endonezya & 2,45 \\
81 & Brezilya & 2,45 \\
82 & Bosna Hersek & 2,39 \\
$\ldots$ & $\ldots$ & $\ldots$ \\
\hline & Dünya Ortalaması (141 Ülke) & $\mathbf{2 , 4 0}$ \\
\hline
\end{tabular}

(CISCO, 2019)

Aynı şekilde Türkiye bu puan ile Paraguay, Suudi Arabistan, Endonezya, Brezilya ve Bosna Hersek ülke grubunda yer almaktadır. Beşeri sermaye konusunda Türkiye'nin dünya ortalaması düzeyinde yer alması konusunda; işgücü katılım oranlarının OECD ortalamasının

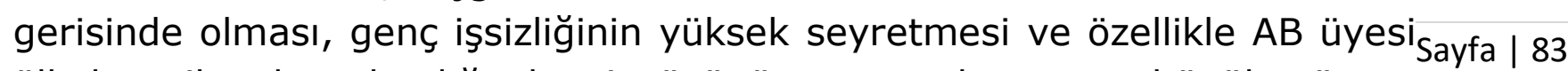
ülkeler ile kıyaslandığında işgücünün sayısal artışı büyük önem taşımaktadır (Grafik 5).

Grafik 5: İşgücüne Katılım Oranı, İşgücü ve Genç İşsizliği

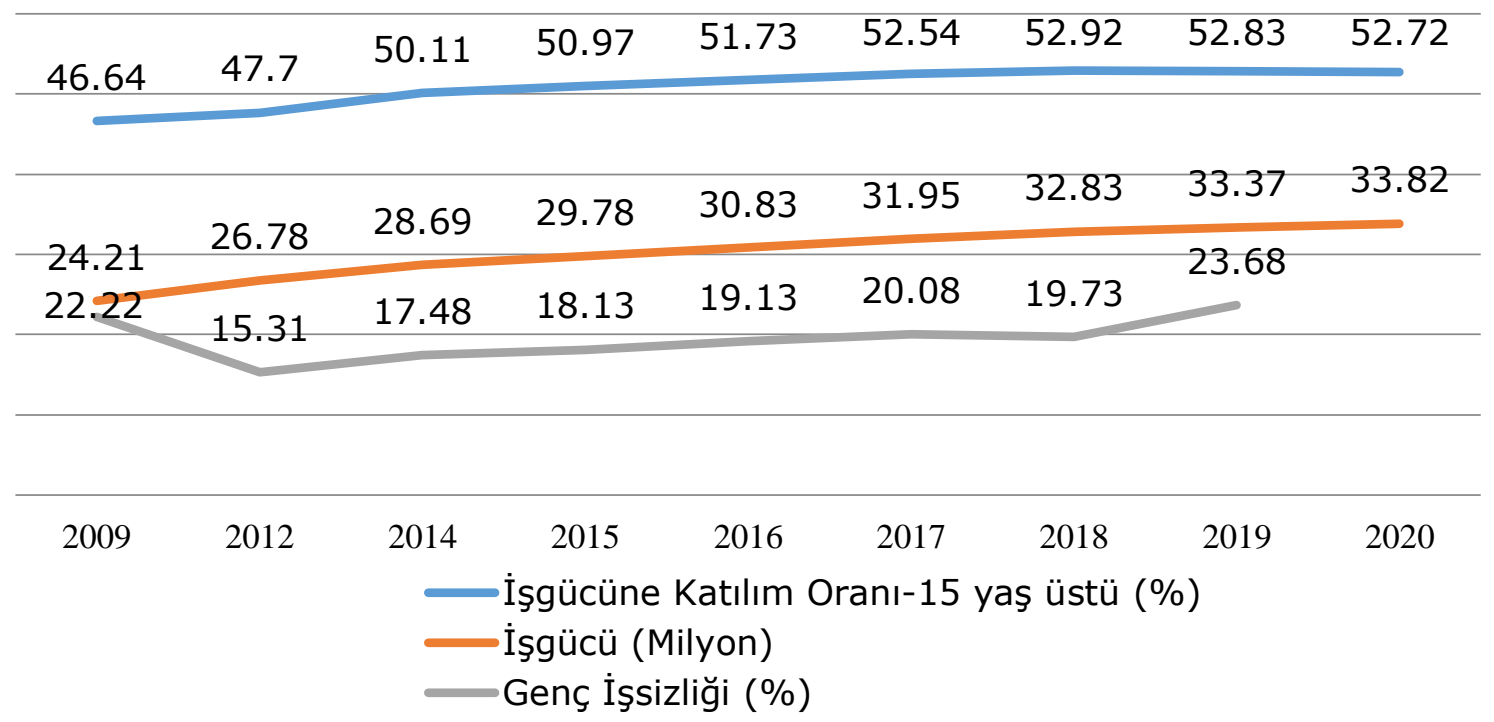

(Worldbank, 2020)

Grafik 5'e göre kriz ertesi yılda \%46,64 olan işgücüne katılım oranı zaman içerisinde kısmen bir artış göstererek 2020 yılında \%52,72 olarak gerçekleşmiştir. Aynı şekilde 24,21 milyon civarında olan işgücü, 2020 
yılında 33,82 milyona ulaşmış, \%22,22 civarında olan genç işsizliği ise zaman içinde önemini korumuş hatta 2019 yılı itibariyle bu oran son on yılın en yüksek seviyesine ulaşmıştır. Ayrıca beşeri sermaye konusunda Türkiye ile ilgili şu tespitler dikkat çekmektedir:

- Özellikle işgücüne katılım oranı 25-64 yaş grubu için dikkate alındığında 2019 yılı için bu oranın \%62,3 olarak gerçekleşmesi ve OECD ortalamasının \%78,4 olması bu kapsamda önemli bir sorun alanını oluşturmaktadır. Aynı şekilde genç işsizliğinin yüksek olması da bu noktada dikkat çekicidir (Oecd, 2020).

- Öte yandan 2007 yılında \%88 olan yetişkin okuryazarlık oranı 2017 yılı itibariyle \%96'ya yükselmiştir. Bahsedilen 10 yıl zarfında en çarpıcı gelişme kadınların okuryazarlık oranlarında yaşanan artış olmuştur. Buna göre 2007 yılında \%81,26 olan bu oran 2017'de $\% 93,5$ olarak gerçekleşmiştir. Aynı zaman diliminde erkeklerde ise bu oran \%96,20'den \%98,82'ye yükselmiştir (Statista, 2020).

- İnsani gelişim endeksinde 1990 'larda 0,6'nın altında olan Türkiye, 2010 yılı itibariyle 0,7'nin üzerine çıkmış ve 2018 yılı itibariyle 0,81 puan ile 59. sırada yer almıştır. Bu kapsamda eğitim süresi 1990 'da 8,9 yıl, 2000'de 11,1 yıl, 2005'te 11,9 yıl, 2010'da 13,9 yıl, 2015'te 16,2 yıl ve 2018 'de 16,4 yıl şeklinde gelişim göstermiştir. (Hdr, Sayfa | 84 2020).

- Bir diğer önemli konu ise uyumlaştırımış test puanıdır. En az 300 en fazla 625 olarak hesaplanan ve içinde TIMSS (Uluslararası Matematik ve Fen Çalışmalarında Trendler), PIRLS (Uluslararası Okuryazarlık Çalışmalarında İlerleme Süreci), PISA (Uluslararası Öğrenci Değerlendirme Programı), SACMEQ (Eğitim Kalitesini İzleme Güney ve Doğu Afrika Konsorsiyumu), PASEC (CONFEMEN Eğitim Sistemleri Analiz Programı) göstergelerinin bulunduğu uyumlaştırılmış test puanında Türkiye; 2020 yılı itibariyle 478 puanda yer almaktadır. Aynı şekilde Beşeri Sermaye Endeksinde Türkiye, 2020 yılı itibariyle 0,65 puanda gösterilmektedir (2010'da 0,63 ). Diğer bir ifade ile bugün Türkiye'de doğan bir çocuk tam bir eğitim alırsa ve sağlık hizmetlerinden faydalanırsa büyüdüğünde $\% 65$ verimli olacaktır. Bu oran Avrupa ve Orta Asya ortalamasından düşük ancak üst orta gelirli ülkelerin ortalamasından yüksek bir görünüm arz etmektedir (Worldbank, 2020).

Bu kapsamda özellikle işgücüne katılım oranının OECD ortalamasının oldukça gerisinde olması, işgücü piyasasına giren birey sayısının sürekli artması ve genç işsizliğinin oldukça yüksek seyretmesi, dijital dönüşüm sürecinde çözümlenmesi gereken sorunların başında gelmektedir. Öte 
yandan özellikle kadınlar arasında okuryazarlık oranının giderek artması olumlu bir gelişme iken uyumlaştırılmış test puanının ortalama bir görünüm arz etmesi ve aynı zamanda beşeri sermaye endeksi puanının Avrupa ve Orta Asya ülke ortalamalarının gerisinde olması dijitalleşme sürecinde gerekli olan vasıflı işgücünün oluşturulması noktasında büyük önem taşımaktadır.

\subsection{Start-Up Çevresi}

1990'larda yaygın bir girişim türü olan dotcomlara karşılık startup'lar; kurucuların pazara sunmak istediği tek bir ürün veya hizmete odaklanan şirketler veya girişimler olarak tanımlanmaktadır (Grant, 2020). Yeni girişim olarak da Türkçeleştirilebilen start-uplar, özellikle bilgi tabanlı dönüşüm ile çoğunlukla teknoloji alanında yapılan girişimleri tanımlamak için kullanılmaktadır. Bu kapsamda dijital dönüşüm sürecinde her geçen gün önemi daha da artan start-up çevresi dijital dönüşüm sürecinin en önemli girdilerinden birini oluşturmaktadır. CISCO dijital hazırlık endeksinde start-up çevresi:

- Yeni iş yoğunluğu

- Verilen patentler ve tescilli ticari markalar

- Risk sermayesi yatırımı ve kullanılabilirliği

olmak üzere üç temel kategori çerçevesinde ele alınmıştır. Bu kategorilere bağlı olarak Türkiye 3 üzerinden yapılan puanlamada 0,32 puan ile ortalamanın altında yer almaktadır. Aynı şekilde Lüksemburg, Singapur, İzlanda, ABD, Yeni Zelanda gibi ülkelerin ilk sıralarda yer aldığı endekste Türkiye; Tacikistan, Pakistan, Namibya, Kazakistan, Guatemala ülke grubunda yer almaktadır (Tablo 5). 
Tablo 5: Start-up Bileşeninde Türkiye

\begin{tabular}{ccc}
\hline Sıra & Ülke & Puan (3 üzerinden) \\
\hline 1 & Lüksemburg & 2,56 \\
\hline 2 & Singapur & 1,66 \\
3 & İzlanda & 1,45 \\
4 & ABD & 1,40 \\
5 & Yeni Zelanda & 1,33 \\
$\ldots$. & $\ldots$ & $\ldots$ \\
70 & Tacikistan & 0,33 \\
71 & Pakistan & 0,32 \\
72 & Türkiye & $\mathbf{0 , 3 2}$ \\
73 & Namibya & 0,32 \\
74 & Kazakistan & 0,31 \\
75 & Guatemala & 0,31 \\
$\ldots$ & $\ldots$ & $\mathbf{0 , 4 5}$ \\
& Dünya Ortalaması (141 Ülke) & \\
\hline
\end{tabular}

Tablo 5'e göre dijital hazırlık endeksinde Türkiye'nin start-up çevresi sorunlu bir alanı oluşturmaktadır. Aynı şekilde start-up çevresine bağlı olarak diğer sorunlu alanlar ise; iş yoğunluğu, teknopark sayıları, kredi risk sermayesi fon sayıları ve start-up hızlandırıcı sayılarının yetersizliği şeklinde görülmektedir. Bu kapsamda hesaplanan (15-64 yaş grubunda 1000 kişi başına düşen) yeni iş yoğunluğu sayıları Türkiye'de 2013 yılındaSayfa | 86 0,97 iken 2014'te 1,04 2015'te 1,25 2016'da 1,18 2017'de 1,37 2018'de 1,56 şeklinde gerçekleşmiştir. Dünya Ortalaması 1,5 olan rakamın, OECD ortalaması 3,7 AB ortalaması ise 3,8'dir (Worldbank, 2020). Aynı şekilde Türkiye'de ulusal ticari marka başvuruları normal bir düzeyde iken (Grafik 6) start-up hızlandırıcı, teknopark ve kurumsal kredi risk sermayesi fonu sayıları ortalamaların oldukça gerisinde bir görünüm arz etmektedir (Grafik 7). 


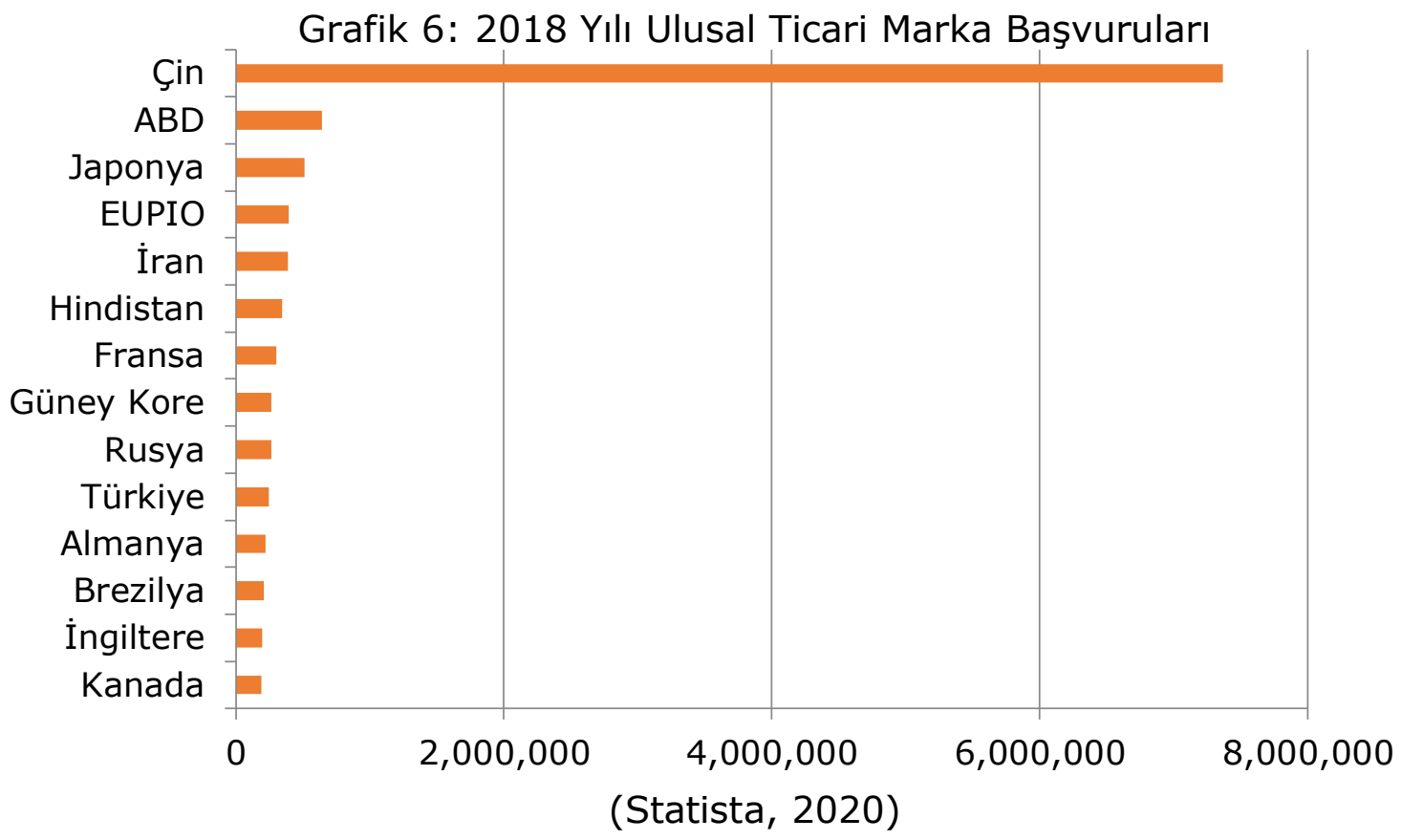

Mevcut bir girişimin büyümesini sağlayan hızlandırma desteği sağlayan kurum sayısı 2019 yılı itibariyle toplamda 57 iken kurulan teknopark sayısı 61 olmuştur. Özellikle şirketlerin start-up çerçevesinde destekleyici olmaları ve onları bu ekosistemde aktif uyumlu özelliği kazandırmaları açısından büyük önem taşıyan Kurumsal Risk sermayesisayfa | 87 Fon sayıları 2019 yılı itibariyle toplamda 26'ya ulaşmıştır. Bu kapsamda 2018 yılı itibariyle yıllık bazda gerçekleşen bu faaliyetlerin aşağı yönlü olması dijital dönüşüm sürecinde; iş yoğunluğunun, verilen patentlerin ve ticari marka sayılarının arttırılması konusunda yeni önlemlerin alınması ihtiyacını ön plana çıkarmaktadır (Grafik 7). 
Grafik 7: Türkiye'de Start-up Hızlandırıcı, Teknopark ve Kurumsal Kredi Risk Sermayesi Fonu Sayıları

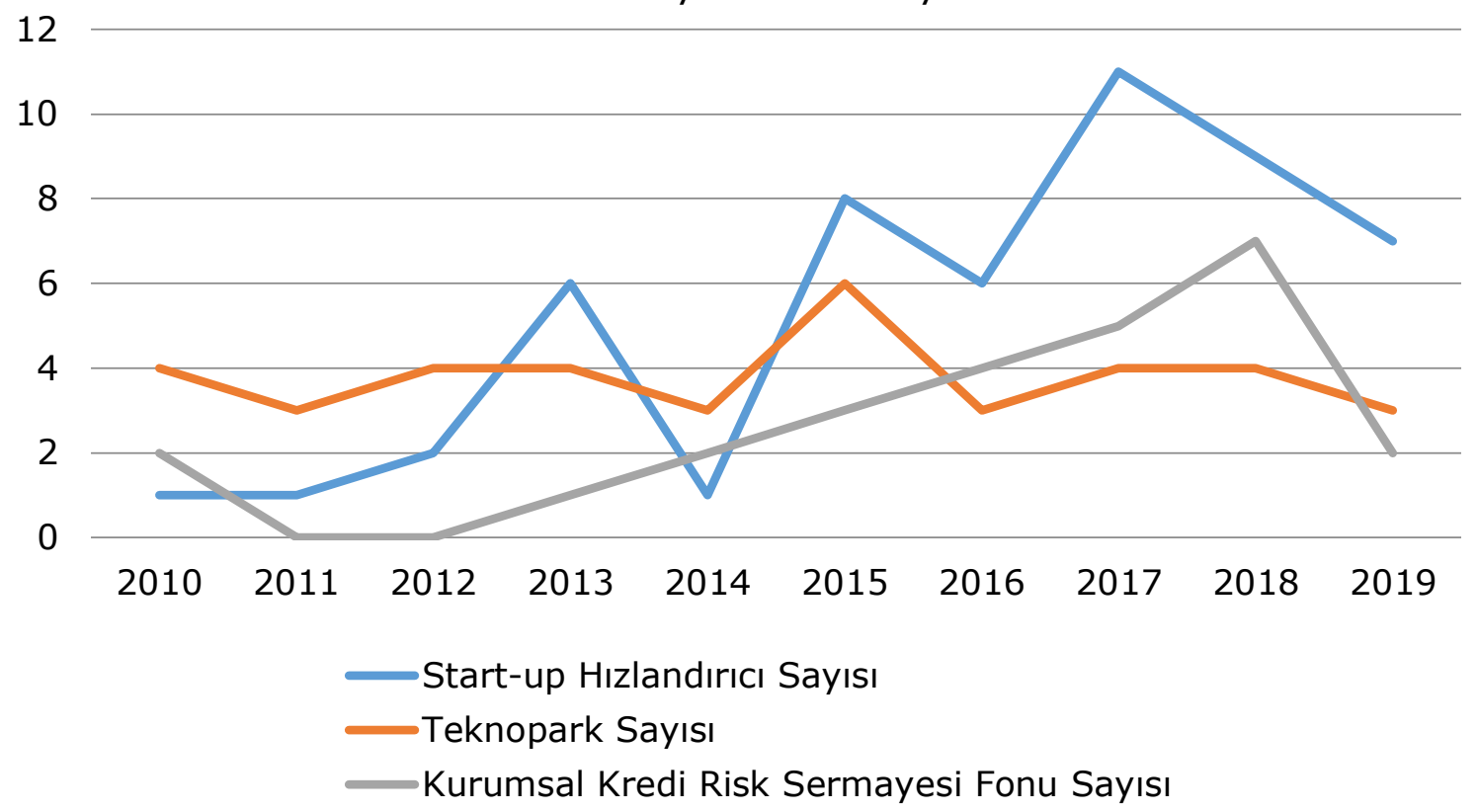

(Presidency of the Republic of Turkey Investment Office, 2020)

Grafik 7'ye göre iş yapma yoğunluğu açısından $O E C D$ ve $A B$ ortalamalarının gerisinde bulunan Türkiye'de özellikle son üç yıldır start-up hızlandırıc sayısının, teknopark sayısının ve kurumsal risk sermayesi fon ${ }_{\text {Sayfa }} 88$ sayısının azalma eğiliminde olması start-up çevresinde yaşanan sorun alanlarını göstermektedir. Aynı şekilde 2018 yılında en fazla ulusal ticari marka başvurusu yapan ülkeler sıralamasında Çin, ABD, Japonya ilk sıralarda yer alırken Türkiye'nin; Kanada, İngiltere, Brezilya, Almanya gibi ülkeleri geride bırakarak 9. sırada yer alması bir bakıma umut vericidir (Grafik 7). Diğer bir ifade ile Türkiye start-up çevresi bileşeninde ulusal ticari marka kategorisinde önemli derecede sorun yaşamazken start-up hızlandırıc sayısı, teknopark sayısı ve kurumsal kredi risk sermayesi fon sayılarını acilen arttırması gerekmektedir.

\subsection{Teknolojiyi Benimseme}

Dijital hazırlık sürecinde önemli bir konuyu da toplumun teknolojiyi benimseme boyutu oluşturmaktadır. CISCO dijital hazırlık endeksinde bu bileşen;

- Mobil cihaz penetrasyonu,

- İnternet Kullanımı,

- Bulut hizmetleri,

kategorileri ile birlikte ele alınmıştır. Buna göre mobil cihaz penetrasyonu, internet kullanımı ve bulut hizmetleri kategorilerinden oluşan teknolojiyi benimseme bileşeninde Türkiye; 3 üzerinden yapılan puanlamada 1,01 
puan ile ortalamanın altında yer almaktadır. Diğer bir ifade ile $A B D$, Kanada, Lüksemburg, Singapur ve Birleşik Arap Emirlikleri'nin (BAE) ilk sıralarda yer aldığı endekste Türkiye; Filipinler, Gabon, İran ve Meksika gibi ülkelerle aynı kategoride yer almaktadır (Tablo 6).

Tablo 6: Teknolojiyi Benimseme Bileşeninde Türkiye

\begin{tabular}{ccc}
\hline Sıra & Ülke & Puan (3 üzerinden) \\
\hline 1 & $\mathrm{ABD}$ & 2,22 \\
2 & Kanada & 2,05 \\
3 & Lüksemburg & 2,03 \\
4 & Singapur & 1,96 \\
5 & $\mathrm{BAE}$ & 1,82 \\
$\ldots$ & $\ldots$ & $\ldots$ \\
74 & $\ldots$ & 1,02 \\
75 & Filipinler & 1,01 \\
76 & Gabon & $\mathbf{1 , 0 1}$ \\
77 & Türkiye & 1,01 \\
78 & İran & 0,99 \\
$\ldots$ & Meksika & $\ldots$ \\
\hline & $\ldots$ & $\mathbf{1 , 0 4}$ \\
\hline
\end{tabular}

$$
\text { (CISCO, 2019). }
$$

Özellikle hane halkı açısından değerlendirilen teknolojiyi benimseme bileşeni, bilgisayar ve internet kullanımının yanı sıra internet erişimi ${ }^{\text {Sayfa | } 89}$ konularını kapsamaktadır. 2000'li yılların başından itibaren Türkiye'de artan bir ivme kazanan bu gruptaki gelişmeler son birkaç yıl zarfında önemli sayılabilecek boyutlara ulaşmıştır. Ancak dijital hazırlık endeksinde Türkiye'nin bu konuda genel ortalamanın altında değerlendirilmesi belirtilen kategorinin beklenilen düzeyde olmadığını göstermektedir. Bu kapsamda TÜİK verilerine göre hane halkı bilgisayar kullanımı, hane halkı internet kullanımı ve hane halkı internet erişimi hızla yaygınlaşmaktadır. Ancak bu oranların halen aynı düzeydeki ülkelere kıyasla düşük olması teknolojiyi benimseme boyutunun istenilen düzeyde olmadığının bir göstergesi olarak yorumlanabilir (Grafik 8). 
Grafik 8: Hanehalkı Bilişim Verileri (\%)

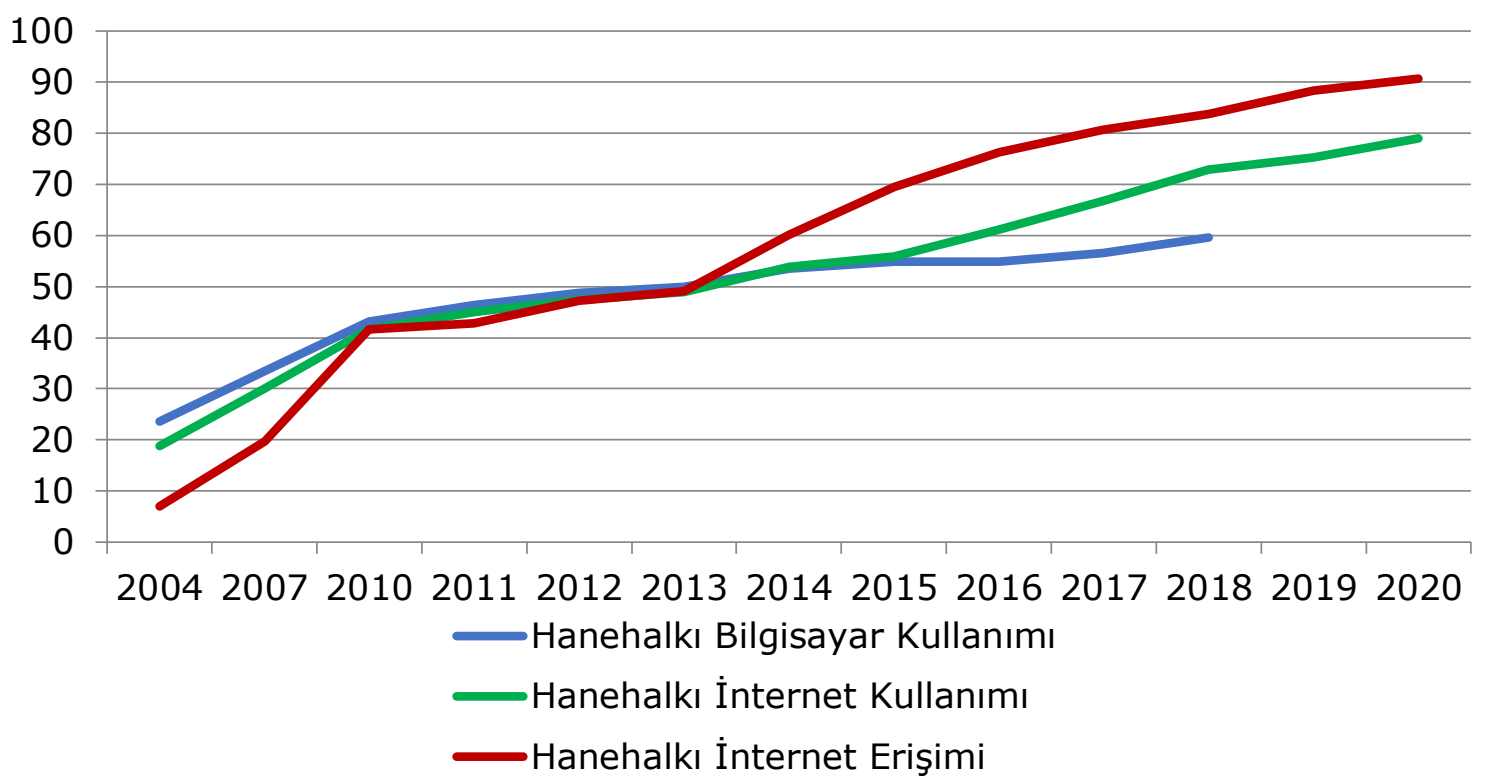

(TÜİK, 2020)

Grafik 8'e göre 2004 yılında \%10'nun altında olan hane halkı internet erişimi 2020 yılı itibariyle \%90'nın üzerine çıkmıştır. Benzer bir ivme internet kullanımında da görülürken en sorunlu alan olarak hane halkı bilgisayar kullanımı göze çarpmaktadır. 2004 yılında \%20'inin biraz ${ }_{\text {Sayfa | } 90}$ üstünde olan hane halkı bilgisayar kullanım oranı, 2018 yılı itibariyle $\% 60$ civarında seyretmektedir. Diğer bir ifade ile 2000'li yılların başlarında oldukça düşük oranda gerçekleşen teknolojiyi benimseme gelişmeleri, özellikle son üç yıldır önemli oranda yükselme eğilimine girmiştir. Ancak bu durum diğer ülkeler ile birlikte değerlendirildiğinde özellikle bilgisayar kullanımının yeterli düzeyde olmaması önemli bir sorun alanını oluşturmaktadır.

\subsection{Teknolojik Alt Yapı}

Teknolojiyi benimseme bileşenine bağlı olarak dijital dönüşüm sürecinde önemi vurgulanan bir diğer konu da söz konusu ülkenin teknolojik alt yapısıdır. CISCO dijital hazırlık endeksinde bu bileşen;

- Mobil geniş bant abonelikleri,

- Sabit geniş bant abonelikleri,

- Güvenli internet sunucuları,

- Ev internet erişimi

kategorileri ile tanımlanmaktadır. Bu kapsamda 4 üzerinden yapılan puanlamada Danimarka, Hollanda İsviçre, İzlanda ve Singapur ilk sıralarda yer alırken Türkiye 1,40 puan ile ortalamanın biraz üstünde Sırbistan, 
Makedonya, Gürcistan ve Umman gibi ülkeler grubunda yer almaktadır (Tablo 7).

Tablo 7: Teknolojik Alt Yapı Bileşeninde Türkiye

\begin{tabular}{ccc}
\hline Sıra & Ülke & Puan (4 üzerinden) \\
\hline 1 & Danimarka & 3,44 \\
\hline 2 & Hollanda & 3,12 \\
3 & İsviçre & 2,85 \\
4 & İzlanda & 2,85 \\
5 & Singapur & 2,84 \\
$\ldots$ & $\ldots$ & $\ldots$ \\
52 & Sırbistan & 1,45 \\
53 & Makedonya & 1,41 \\
54 & Türkiye & $\mathbf{1 , 4 0}$ \\
55 & Gürcistan & 1,40 \\
56 & Umman & 1,38 \\
$\ldots$ & $\ldots$ & $\ldots$ \\
\hline & Dünya Ortalaması (141 Ülke) & $\mathbf{1 , 1 7}$ \\
\hline
\end{tabular}

(CISCO, 2019)

Dijital dönüşüm süreci bir ülke için; fiber optik ağlar başta olmak üzere, sahip olunan bilgisayarların donanımı, yazılımı, kapasite ve hızları, veri yönetimi, abonelik düzeyleri, güvenli sunucular vb. birçok konuyu kapsar bir nitelik taşımaktadır. Diğer bir ifade ile dijital dönüşüm hızınaSayfa | 91 uyum sağlama süreci sağlam bir teknolojik alt yapı gerektirmektedir. Bu kapsamda Türkiye'de özellikle 2010 yılı sonrasında mobil hücresel abonelikler bazında yaşanan gelişmeler ve güvenli internet sunucularındaki sayısal artış dönüşüm sürecine uyum sağlama sürecinde önem kazanmıştır (Grafik 9/ Grafik 10). 
Grafik 9: İnternet Kullanan Birey Sayısı (Nüfusun Yüzdesi) ve Abonelikler 80

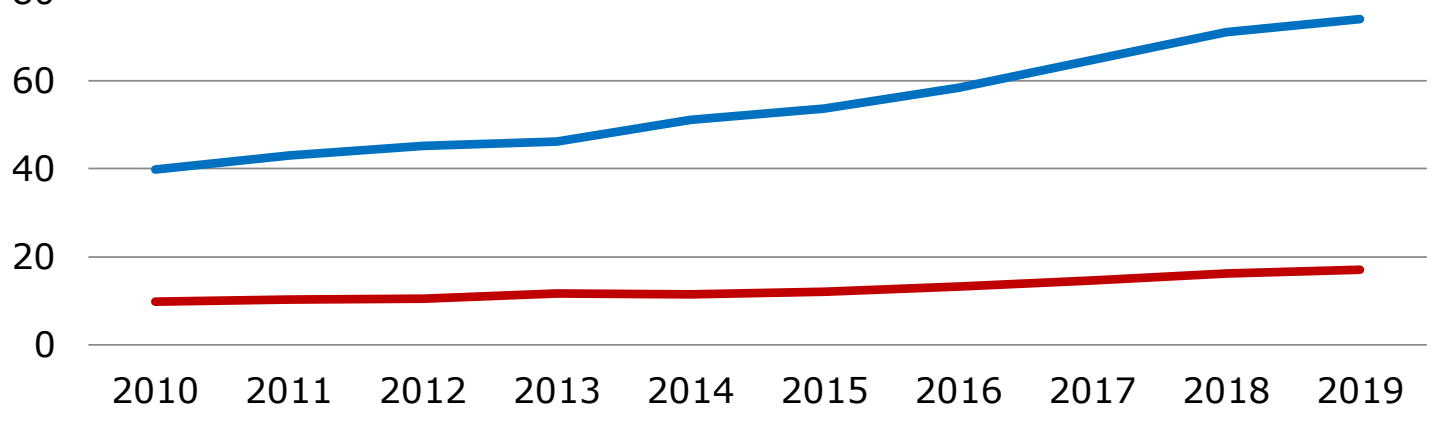

İnternet Kullanan Bireyler (Nüfusun \%'desi) ya da Mobil Hücresel Abonelikler (\%)

— Sabit Geniş Bant Abonelikleri (100 Kişi Başına)

(Worldbak, 2020)

Grafik 9'da da görüldüğü üzere 2010 yılında \%40 civarında olan mobil hücresel abonelik sayısı artan bir ivme ile 2019 yılı itibariye \%70 bandını aşmıştır. 2010 yılı itibariyle $\% 10$ civarında olan sabit geniş bant abonelik oranı ise daha yavaş bir artışla 2019 yılı itibariyle \%20 bandının altında kalmıştır. Teknoloji alt yapısı konusunda bir diğer konu ise güvenli internet sunucu sayılarıdır. 2010-2015 yılları arasında 0-50.000 arasında olan güvenli internet sunucu sayıları 2019 yılı itibariyle 450.000 bandını Sayfa | 92 aşmıştır (Grafik 10).

Grafik 10: Güvenli İnternet Sunucuları

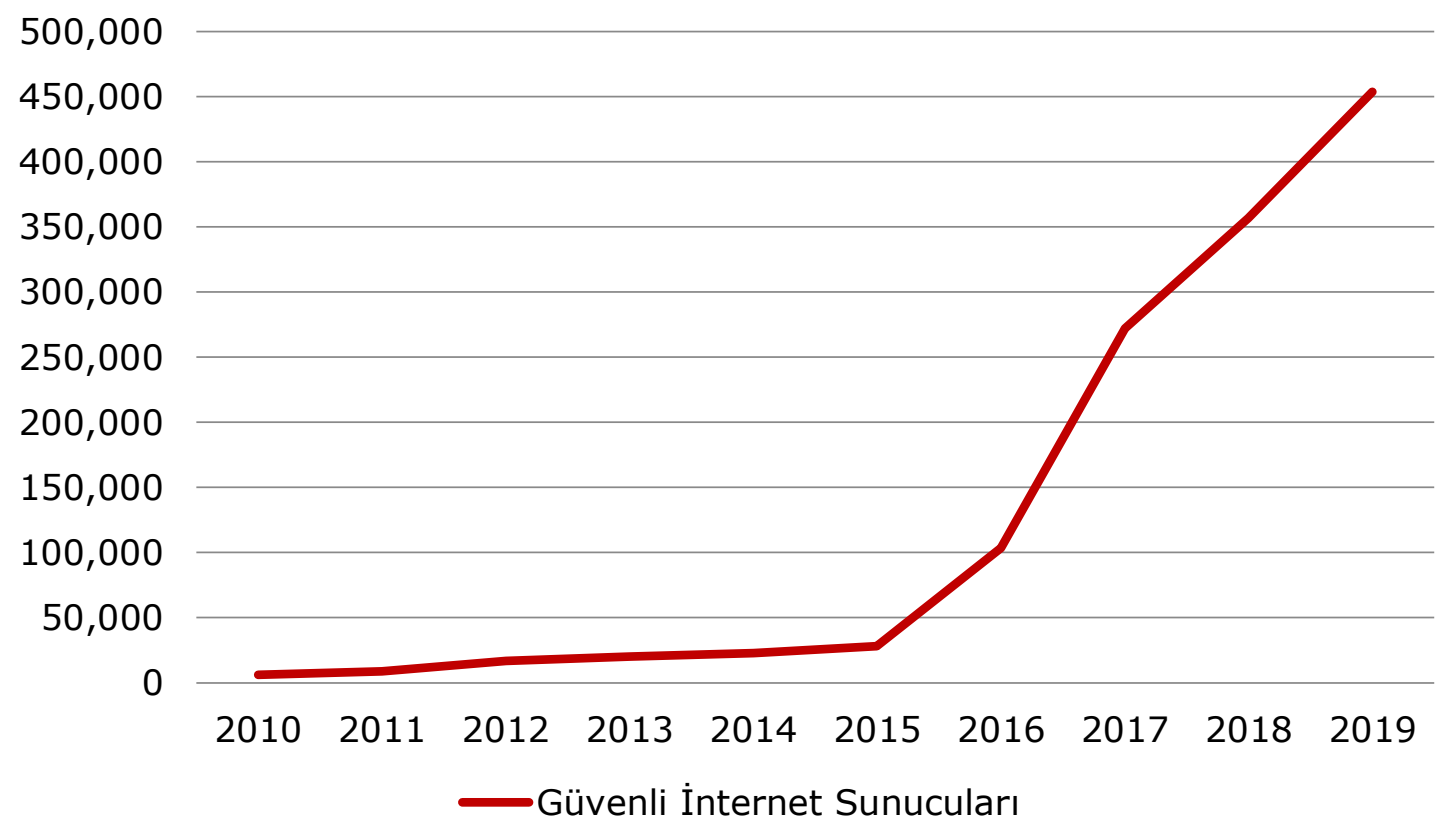

(Worldbank, 2020)

Grafik 9 ve Grafik 10'dan hareketle Türkiye'de internet kullanan bireyler ya da mobil hücresel abonelik sayısı; sabit geniş bant abonelikleri 
ve güvenli internet sunucu sayılarında bir artış eğiliminin olduğunu söylemek mümkündür. Bu artış güvenli internet sunucu sayılarında özellikle 2015'ten sonraki dönemde hızlı, mobil hücresel aboneliklerde yavaş, sabit geniş bant aboneliklerinde ise daha yavaş gerçekleşmiştir. Diğer bir ifade ile teknoloji alt yapısında yer alan kategorilerin istenilen düzeyde ve istenilen hızda gelişme göstermesine rağmen genel anlamda halen ortalamanın çok az üzerinde olması ve gelişmekte olan ülkeler kategorisinin gerisinde yer alması dijital dönüşümün önemli bir sorun alanını oluşturmaktadır.

\section{GENEL GÖRÜNÜM}

CISCO dijital hazırlık endeksinin birinci kategorisi olan temel intiyaçlar kategorisine göre Türkiye'de; ortalama yaşam beklentisi yükselmektedir, bebek ölüm oranları düşmektedir, elektriğe erişim \%100'e ulaşmıştır. Ancak güvenli içme suyu erişimi ve geleceği konusunda atık su kontrolü, yeraltı sularının kirlenmesi, kimyasal gübreler, ormansızlaşma, yetersiz ve yanlış tarımsal uygulamalar temel sorun alanlarını oluşturmaktadır. İşletme ve devlet yatırımları kategorisinde ise önemli bir teknoloji transfer yöntemi olarak kullanılan DDY'lerde özellikle son dört yılda daralmalar yaşanmaktadır. Bunun yanında ar-ge'ye ayrılan bütçe OECD ortalamasının gerisinde iken ekonomik özgürlük ve serbest piyasa Sayfa | 93 uygulamalarının etkisi kapsamında ekonomik durgunluk, hukukun üstünlüğü, yolsuzlukla mücadele, vergi yükü ve parasal özgürlük konuları temel sorun alanlarını oluşturmaktadır. Aynı şekilde iş yapma kolaylığı kapsamında Türkiye; iş kurma, üretim izni, elektrik enerjisi, kredi sağlama, mülkiyet, yatırımcılığın korunması, vergi ödeme, sınırlar arası düzenlemeler, sözleşmeler, hükümet ile anlaşma, gümrük, lojistik alt yapısı, izleme, izlenme ve zaman başlıkları iyi sayılabilecek bir düzeyde değerlendirilirken kısıtlamalar, yolsuzluk, şeffaflık, temel hakların kullanılması, düzen ve güvenlik konuları başlıca sorun alanlarını oluşturmaktadır.

Bunun yanında beşeri sermaye konusunda Türkiye'de; işgücüne katılım oranı, OECD ortalamasının oldukça gerisinde bir görünüm arz etmektedir. Ayrıca doğum oranlarına bağlı olarak işgücü arzının artmaya devam etmesi ve genç işsizliğinin artış eğiliminde olması dengeli bir işgücü piyasasının oluşmaması noktasında büyük önem taşımaktadır. Ayrıca okuryazarlık oranlarının özellikle kadınlar arasında sürekli olarak artması olumlu bir yönü oluştururken matematik, fen çalışmaları ve diğer öğrenci değerlendirme kategorilerinde uyumlaştırılmış test puanının ve insani gelişim endeksinin $O E C D$ ve $A B$ ülkeleri ortalamalarının gerisinde olması 
bu kapsamdaki görülen sorun alanlarını göstermektedir. Start-up çevresi kategorisinde ise Türkiye'de; iş yapma yoğunluğu $A B$ ve $O E C D$ ortalamalarının gerisinde bir görünüm arz etmektedir. Aynı şekilde star-up çevresini destekleyen teknopark sayıları, kredi risk sermayesi fon sayıları, start-up hızlandırıcı sayıları endeks ortalamasının gerisinde yer almaktadır. Verilen patentlerin ve ticari marka sayılarının arttırılması da bu kapsamda değerlendirilebilecek temel sorun alanları arasında yer almaktadır.

Dijital dönüşüm sürecinde önemli bir boyutu oluşturan teknolojiyi benimseme konusunda TÜİK verilerine göre Türkiye'de; hane halkı bilgisayar kullanımı, hane halkı internet kullanımı ve hane halkı internet erişimi özellikle son on yılda önemli oranda artış göstermiştir. Ancak bu kategorilere bağlı olarak tanımlanan teknolojiyi benimseme göstergesinin halen endeks ortalamasının gerisinde kalması bu alanda yeni yatırımların yapılması gerektiğini göstermektedir. Buna bağlı olarak dijital dönüşüm sürecinin sağlam ve kapsamlı bir teknolojik alt yapı ile şekillenmesi gereği; mobil geniş bant abonelikleri, sabit geniş bant abonelikleri ve ev internet erişim kategorilerinin önemini ön plana çıkarmaktadır. Buna göre Türkiye'de özellikle 2015 yılından itibaren katlanarak artan güvenli internet sunucu sayılarına karşılık mobil hücresel abonelikleri ve sabit geniş bant aboneliklerinde daha yavaş artış görülmektedir. Bu konudaSayfa | 94 Türkiye'nin ortalamaların çok az üstünde yer alması ve genellikle teknolojik bakımdan gelişmekte olan ülkeler kategorisinin gerisinde gösterilmesi bu alanlarda yeni yatırımların yapılması gereğini ön plana çıkarmaktadır.

Öte yandan CISCO dijital hazırlık endeksinde dikkate alınan tüm bileşenler birlikte ele alındığında belirlenen 25 puan üzerinden Türkiye, 12,88 puan ile ortalama düzeyde bir görünüm arz etmektedir (Tablo 8 ).

Tablo 8: Dijital Dönüşüm Sürecinde Türkiye

\begin{tabular}{cccl}
\hline Sır & Ülke & Puan (25 üzerinden) & Kategori \\
$\mathbf{a}$ & Singapur & 20,26 & Güçlendir \\
\hline 1 & Lüksemburg & 19,54 & Güclendir \\
2 & ABD & 19,03 & Güçlendir \\
3 & Danimarka & 18,98 & Güçlendir \\
4 & İsviçre & 18,86 & Güçlendir \\
\hline
\end{tabular}




\begin{tabular}{cccc}
\hline$\ldots$ & $\ldots$ & $\ldots$ & \\
57 & Arjantin & 13,06 & Hızlandır (Yüksek) \\
58 & Belarus & 12,95 & Hızlandır (Yüksek) \\
59 & Türkiye & 12,88 & Hızlandır (Yüksek) \\
60 & Makedonya & 12,78 & Hızlandır (Yüksek) \\
61 & Azerbaycan & 12,77 & \\
$\ldots$ & $\ldots$ & $\ldots$ & \\
& Dünya Ortalaması & 11,90 & \\
\hline
\end{tabular}

(CISCO, 2019)

Aynı şekilde Singapur, Lüksemburg, ABD, Danimarka, İsviçre'nin ilk sıralarda yer aldığı genel sıralamada Türkiye; Arjantin, Belarus, Makedonya, Azerbaycan ile aynı kategoride yer almaktadır. Aynı şekilde hızlandır (yüksek) kategorisi dijital dönüşüm sürecinde Türkiye'nin; temel intiyaçlar, işletme ve devlet yatırımları, iş yapma kolaylığı, beşeri sermaye, start-up çevresi, teknolojiyi benimseme ve teknolojik alt yapı konularında genel anlamda yeterli düzeyde olmadığını göstermektedir.

\section{SONUÇ VE ÖNERİLER}

CISCO dijital hazırlık endeksi, geliştirilen diğer hazırlık endekslerinden farklı olarak dönüşüm sürecini daha kapsamlı, daha gerçekçi ve sürdürülebilir kalkınmanın önemli bir uzantısı olarak Sayfa | 95 değerlendirmektedir. Bu kapsamda CISCO hazırlık endeksi belirlemiş olduğu yedi bileşen çerçevesinde ülkelere; hazırlık sürecini tanımlama, hazırlanma, eksikleri görme, politika ve strateji belirleme konularında önemli veriler sunmaktadır. Özellikle gelişmekte olan ülkeler için önemli bir süreci ifade eden dijital dönüşüm süreci Endüstri 4.0'ın yaşanmasında da bir köprü özelliği taşımaktadır. Diğer bir ifade ile küresel rekabetin sürdürülebilir olması ve aynı zamanda toplumsal kalkınmanın sağlanması konusunda dijital dönüşümün gereklerini belirlemek ve hayata geçirmek, çok hızlı değişen ve dönüşen küresel (dijital) dünyada en önemli konu haline gelmiştir. Buna göre gelişmekte olan ülkeler kategorisinde değerlendirilen Türkiye'nin dijital dönüşümü tanımlaması ve gerekliliklerini bugünden yerine getirmesi, küresel rekabet ve toplumsal kalkınma konularında önemli avantajlar sağlayacaktır. Bu kapsamda CISCO hazırlık endeksinde belirlenen bileşenler çerçevesinde Türkiye'nin temel sorun alanları şu şekilde belirtilebilir:

- Temel ihtiyaçlar kapsamında; güvenli içme suyu konusunda su sıkıntısı çeken ülke konumunda ve su fakiri olma yolunda ilerlemektedir.

- İşletme ve devlet yatırımları kapsamında; teknoloji transferi adına büyük önem taşıyan yabancı yatırımlar azalma eğilimde 
özellikle bütçeden ar-ge'ye ayrılan pay OECD ortalamasının çok gerisinde, hukukun üstünlüğü ve 2018 sonrası ekonomik durgunluk konusu temel sorun alanlarını oluşturmaktadır.

- İş yapma kolaylığı kapsamında; iş yapma kolaylığı endeksi, lojistik performans ve elektriğe ulaşım verileri artma eğiliminde ancak $A B$ ve $O E C D$ ortalamalarının gerisinde bir görünüm arz etmektedir. Ayrıca hukukun üstünlüğü konusunda en düşük kategoriye sahip ülke gruplarına oldukça yakın gösterilmektedir

- Beşeri sermaye kapsamında; işgücüne katılım oranı OECD ortalamasının oldukça gerisindedir ve genç işsizliğinin yüksek seyretmesi önemli bir problem olarak karşımıza çıkmaktadır. Ayrıca uyumlaştırılmış test puanının ortalama bir düzeyde seyretmesi vasıflandırma sürecinde yeni önlemlerin alınmasını gerekli kılmaktadır.

- Start-up çevresi kapsamında; iş yoğunluğunun $A B$ ve $O E C D$ ortalamasının gerisinde olması, start-up hızlandırıcı, teknopark ve kurumsal risk sermayesi fon sayılarının yeterli düzeyde olmaması ve azalma eğilimde olması önemli bir sorun alanını oluşturmaktadır.

- Teknolojiyi benimseme kapsamında; hanehalkı bilgisayar ${ }_{\text {Sayfa/96 }}$ kullanımı, internete erişim ve kullanım oranları her ne kadar artma eğiliminde olsa da endekste ortalama bir görünüm arz etmesi bu alanda yeni yatırımları gerekli kılmaktadır.

- Teknoloji alt yapısı kapsamında; abonelikler ve güvenli sunucu sayılarında artma eğilimi devam etmektedir. Ancak bu durumun ortalamanın biraz üstünde seyretmesi bu alanda yeni yatırımları gerekli kılmaktadır.

Buna bağlı olarak Türkiye'de dijital dönüşüm sürecinde aşağıda belirtilen politikalara ağırlık verilmesi, hem toplumsal kalkınmanın sağlanmasında hem de küresel rekabetin sürdürülmesi konusunda büyük önem taşımaktadır. Buna göre:

- Güvenli içme suyu ve atık kontrolü devamlılığına yönelik politikalara ağırlık verilmelidir.

- Özellikle teknoloji transferi konusunda önemli bir yöntem olarak kullanılan yabancı yatırımlar teşvik edilmelidir.

- Özellikle dış Dünya'da hukukun üstünlüğü ve 2018 yılı sonrası oluşan ekonomik durgunluk sorunlarına yönelik reformlar hayata geçirilmelidir.

- Orta ve uzun vadede işgücüne katılım oranlarının arttırılmasına ve genç işsizliğine yönelik istihdam politikalarına ağırlık verilmelidir. 
- İşgücünün sadece vasıflandırılması değil uyumlu vasıflandırılması gerekmektedir aynı zamanda eğitimde uygulanan kalite kontrol sistemleri gözden geçirilmelidir.

- Start-up hızlandırıcı kurum sayıları, teknopark sayıları ve kredi risk sermayesi fon sayıları arttırılmalıdır.

- Yeni girişim anlamında iş yoğunlukları arttırımalıdır.

- Bilgisayar kullanımı, internet erişimi ve kullanımının yaygınlaştırılması politikalarına devam edilmeli ve bu kapsamda fiber optik ağlar genişletilmeli ve güçlendirilmelidir.

- Abonelik türlerinin ve güvenli sunucu sayıları arttırılmalı ve bu kapsamda geliştirilen politika ve stratejilere ağırlık verilmelidir.

Belirtilen politikalara öncelik verilmesi sadece dijital dönüşümün başarıyla sağlanması noktasında değil Endüstri 4.0'ın yaşanması noktasında da büyük önem taşımaktadır. Bu kapsamda CISCO dijital hazırlık endeksi ileriye dönük politika ve stratejilerin geliştirilmesi noktasında dikkate değer ipuçları sunmaktadır. 


\section{KAYNAKÇA}

CISCO. (2019). CISCO Readiness Index 2019. Erişim Adresi: https://www.cisco.com/c/m/en_us/about/corporate-socialresponsibility/research-resources/digital-readiness-index.html\#/.

DFKI. (2016). Industrie 4.0: Cyber-Physical Production Systems for Mass Customization.

Grant, M. (2020). Startup. Erişim Adresi: https://www.investopedia.com/terms/s/startup.asp\#: : text $=$ The $\%$ 20term\%20startup $\% 20$ refers\%20to,they\%20believe\%20there\%20i s\%20demand.

Heritage. (2020).

Erişim

Adresi :

https://www.heritage.org/index/country/turkey.

İnternetworld.

(2020).

Erişim

Adresi:

https://www.internetworldstats.com/stats.htm

OECD. (2020). Gross Domestic Spending R\&D. Erişim Adresi: https://data.oecd.org/rd/gross-domestic-spending-on-r-d.htm.

OECD. (2020). Labour Force Pariticipation. Erişim Adresi: https://data.oecd.org/emp/labour-force-participation-rate.htm.

Presidency of the Republic of Turkey Investment Office. (2020). The State Sayfa $\mid 98$ of Turkish Start-up Ecosystem. https://www.invest.gov.tr/en/library/publications/lists/investpublicat ions/the-state-of-turkish-startup-ecosystem.pdf.

Ritzer, G. (2011). Küresel Dünya. İstanbul: Ayrıntı Yayınevi.

Statista. (2020). Global Digital Population as of July 2020. https://www.statista.com/statistics/617136/digital-populationworldwide/ .

Tapscott, D. (1998). Dijital Ekonomi. İstanbul: KoçSistem Yayınları.

The World Bank. (2020). Doing Business. Erişim Adresi: https://www.doingbusiness.org/en/reports/global-reports/doingbusiness-2020.

Tiryakioğlu, M. (2014). Kalkınma İçin Teknoloji-Türkiye'de Teknoloji Transferi Politikaları. Erişim Adresi: http://file.setav.org/Files/Pdf/20140911181541_turkiye\%E2\%80\%9 9de-teknoloji-transferi-politikalari-pdf.pdf.

TUİK. (2020). Erişim Adresi: http://www.tuik.gov.tr/

UNDP. (2020). Expected Years of Schooling (Years). Erişim Adresi: http://hdr.undp.org/en/indicators/69706\# 
World Justice Project. (2019). Rule of Law Index. Erişim Adresi: https://worldjusticeproject.org/sites/default/files/documents/ROLI2019-Reduced.pdf .

Worldbank. (2018). Logistic Performance Index. Erişim Adresi: https://lpi.worldbank.org/international/global/2018.\%202019 .

Worldbank. (2019). Time Required to get Electricity. Erişim Adresi: https://data. worldbank.org/indicator/IC. ELC.TIME?locations=TR

Worldbank. (2020). New business density-Turkey. Erişim Adresi: https://data. worldbank.org/indicator/IC.BUS.NDNS.ZS?locations=TR Erişim Tarihi: 18.10.2020.

Worldbank. (2020). Human Capital Project. Erişim Adresi: https://www.worldbank.org/en/publication/human-capital Erişim Tarihi: 12.10 .2020 ,

WWF. (2020). Tatlı Su. Erişim Adresi: https://www.wwf.org.tr/calismalarimiz/tatli su/ Erişim Tarihi: 12.10.2020.

Worldbank. (2020). Erişim Adresi: https://data.worldbank.org/.

Yıldırım, G. (2019). Küreselleşme ve Çok Uluslu Şirketlerin Teknoloji Transferi: Türkiye Örneği. (Yayınlanmamış Yüksek Lisans Tezi). Marmara Üniversitesi, Sosyal Bilimler Enstitüsü, İktisat Ana Bilim Dalı. İstanbul.

Genişletilmiş Özet: Dijital dönüşüm sürecine uyum sağlamak günümüz toplumlarının önemli bir sorunsalı haline gelmiştir. Dijital altyapı konusunda oldukça avantajlı bir konumda olan gelişmiş ekonomiler ve dijital dönüşüme nispeten uzak olan az gelişmiş ekonomiler hariç tutulduğunda özellikle gelişmekte olan ekonomiler için büyük önem taşıyan bu konu toplumsal kalkınma ve küresel rekabet için kilit faktör özelliği taşımaktadır. Bu noktada özellikle gelişmekte olan ekonomiler için dijital dönüşümün nasıl gerçekleştirileceği ve yönetileceği sorusu, en az dijital dönüşümün ne olduğu sorusu kadar önem taşımaktadır. Buna göre dönüşüm sürecinde; dijital hazırlığın tanımlanması, ölçülmesi, temel sorun alanlarının tespit edilmesi ve müdahale noktalarının belirlenmesi konularının önemi ön plana çıkmaktadır. Diğer dijital hazırlık endekslerine göre oldukça kapsamlı ve gerçeğe uygun veriler sunan CISCO dijital hazırlık endeksi; temel intiyaçlar, işletme ve devlet yatırımları, iş yapma kolaylığı, beşeri sermaye, start-up çevresi, teknolojiyi benimseme ve teknolojik altyapı bileşenleri çerçevesinde dijital dönüşümü tanımlama, anlama, sorun alanlarını tespit etme, politika ve strateji önceliklerini belirleme konularına kaynaklık etmektedir. Bu kapsamda CISCO hazırlık endeksinde belirlenen bileşenlere göre Türkiye'nin temel sorun alanları şu şekilde belirtilebilir: 
- Temel ihtiyaçlar kapsamında; güvenli içme suyu konusunda su sıkıntısı çeken ülke konumunda ve su fakiri olma yolunda ilerlemektedir.

- İşletme ve devlet yatırımları kapsamında; teknoloji transferi adına büyük önem taşıyan yabancı yatırımlar azalma eğilimde özellikle bütçeden arge'ye ayrılan pay OECD ortalamasının çok gerisinde, hukukun üstünlüğü ve 2018 sonrası ekonomik durgunluk konusu temel sorun alanlarını oluşturmaktadır.

- İş yapma kolaylığı kapsamında; iş yapma kolaylığı endeksi, lojistik performans ve elektriğe ulaşım verileri artma eğiliminde ancak $A B$ ve OECD ortalamalarının gerisinde bir görünüm arz etmektedir. Ayrıca hukukun üstünlüğü konusunda en düşük kategoriye sahip ülke gruplarına oldukça yakın gösterilmektedir

- Beşeri sermaye kapsamında; işgücüne katılım oranı OECD ortalamasının oldukça gerisindedir ve genç işsizliğinin yüksek seyretmesi önemli bir problem olarak karşımıza çıkmaktadır. Ayrıca uyumlaştırılmış test puanının ortalama bir düzeyde seyretmesi vasıflandırma sürecinde yeni önlemlerin alınmasını gerekli kılmaktadır.

- Start-up çevresi kapsamında; iş yoğunluğunun AB ve OECD ortalamasının gerisinde olması, start-up hızlandırıcı, teknopark ve kurumsal risk sermayesi fon sayılarının yeterli düzeyde olmaması ve azalma eğilimde olması önemli bir sorun alanını oluşturmaktadır.

- Teknolojiyi benimseme kapsamında; hane halkı bilgisayar kullanımı,Sayfa|100 internete erişim ve kullanım oranları her ne kadar artma eğiliminde olsa da endekste ortalama bir görünüm arz etmesi bu alanda yeni yatırımları gerekli kılmaktadır.

- Teknoloji alt yapısı kapsamında; abonelikler ve güvenli sunucu sayılarında artma eğilimi devam etmektedir. Ancak bu durumun ortalamanın biraz üstünde seyretmesi bu alanda yeni yatırımları gerekli kılmaktadır.

Buna bağlı olarak Türkiye'de dijital dönüşüm sürecinde aşağıda belirtilen politikalara ağırlık verilmesi, hem toplumsal kalkınmanın sağlanmasında hem de küresel rekabetin sürdürülmesi konusunda büyük önem taşımaktadır. Buna göre:

- Güvenli içme suyu ve atık kontrolü devamlılığına yönelik politikalara ağırlık verilmelidir.

- Özellikle teknoloji transferi konusunda önemli bir yöntem olarak kullanılan yabancı yatırımlar teşvik edilmelidir.

- Özellikle dış Dünya'da hukukun üstünlüğü ve 2018 yılı sonrası oluşan ekonomik durgunluk sorunlarına yönelik reformlar hayata geçirilmelidir.

- Orta ve uzun vadede işgücüne katılım oranlarının arttırılmasına ve genç işsizliğine yönelik istihdam politikalarına ağırlık verilmelidir.

- İşgücünün sadece vasıflandırılması değil uyumlu vasıflandırılması gerekmektedir aynı zamanda eğitimde uygulanan kalite kontrol sistemleri gözden geçirilmelidir. 
- Start-up hızlandırıcı kurum sayıları, teknopark sayıları ve kredi risk sermayesi fon sayıları arttırımalıdır.

- Yeni girişim anlamında iş yoğunlukları arttırılmalıdır.

- Bilgisayar kullanımı, internet erişimi ve kullanımının yaygınlaştırılması politikalarına devam edilmeli ve bu kapsamda fiber optik ağlar genişletilmeli ve güçlendirilmelidir.

- Abonelik türlerinin ve güvenli sunucu sayıları arttırılmalı ve bu kapsamda geliştirilen politika ve stratejilere ağırlık verilmelidir

CISCO dijital hazırlık endeksinde Singapur, Lüksemburg, ABD, Danimarka, İsviçre'nin ilk sıralarda yer aldığı genel sıralamada Türkiye; Arjantin, Belarus, Makedonya, Azerbaycan ile aynı kategoride yer almaktadır. Bu durum dijital dönüşüm sürecinde Türkiye'nin; temel ihtiyaçlar, işletme ve devlet yatırımları, iş yapma kolaylığı, beşeri sermaye, start-up çevresi, teknolojiyi benimseme ve teknolojik alt yapı konularında genel anlamda yeterli düzeyde olmadığını göstermektedir. Buna göre dijital dönüşüm sürecinde ülkenin kalkınması ve küresel rekabetin sağlanması konusunda ön plana çıkan başlıklar arasında; güvenli içme suyu ve atık kontrolü, özellikle dış teknoloji transfer eden dış yatırımların teşviki, hukukun üstünlüğünün sağlanması, ekonomik durgunluğun aşılması, orta ve uzun vadede işgücü katılım oranının arttırılması, genç işsizliğinin azaltılması, işgücünün uyumlu vasıflandırılması, start-up hızlandırıcı, teknopark ve kredi risk sermayesi fon sayılarının arttırılması, bilgisayar kullanımı, internete erişim ve kullanımının yaygınlaştırılması ve fiber optik ağların genişletilmesi Sayfa | 101 konuları ön plana çıkmaktadır.

Extended Abstract: Adapting to the digital transformation process has become an important problem of today's societies. This issue is a key factor for social development and global competition, especially for developing economies if developed economies that are in a very advantageous position in digital infrastructure and underdeveloped economies relatively far from digital transformation excludes. At this point, the question of how to realize and manage digital transformation is at least as important as the question of what digital transformation is, especially for developing economies. Accordingly, in the transformation process; It has become important to define and measure digital preparedness, to identify basic problem areas and to identify intervention points. CISCO digital readiness index, which offers comprehensive and realistic data compared to other digital readiness indexes; It provides resources for defining and understanding digital transformation within the framework of basic needs, business and government investments, ease of doing business, human capital, start-up environment, technology adoption and technological infrastructure components, identifying problem areas, setting policy and strategy priorities. According to this Turkey's main problem areas identified in the framework of the components CISCO readiness index is as follows:

- Within the scope of basic needs; It is a country with water shortages in safe drinking water and is on the way to becoming water poor. 
- Within the scope of business and state investments; foreign investments, which are of great importance for technology transfer, tend to decrease. In particular, the share allocated to research and development from the budget is far behind the OECD average. The rule of law and the economic recession after 2018 are the main problem areas.

- Within the scope of ease of doing business; the ease of doing business index, logistics performance and access to electricity data tend to increase, but are behind the EU and OECD averages. It is also shown very close to the country groups with the lowest category of rule of law.

- Within the scope of human capital; the labor force participation rate is well below the OECD average, and the high youth unemployment is an important problem. In addition, the average harmonized test score requires new measures to be taken in the qualification process.

- Within the scope of the start-up environment; the fact that the work intensity is below the EU and OECD average, the number of start-up accelerator, technopark and corporate venture capital funds are not at a sufficient level and they tend to decrease constitute an important problem area.

- Within the scope of technology adoption; although household computer usage, internet access and usage rates tend to increase, their average appearance in the index necessitates new investments in this field.

- Within the scope of technology infrastructure; the trend of increasingSayfa | 102 subscriptions and secure server numbers continues. However, the fact that this situation is slightly above the average requires new investments in this field.

Accordingly, in the digital transformation process in Turkey must be given to the policies outlined below. This issue is of great importance both in ensuring social development and in maintaining global competition. According to this:

- Policies for safe drinking water and waste control continuity should be emphasized.

- Foreign investments, which are used as an important method in technology transfer, should be encouraged.

- Reforms should be implemented especially for the problems of the rule of law in the outside world and the economic stagnation after 2018.

- In the medium and long term, emphasis should be placed on increasing labor force participation rates and employment policies aimed at youth unemployment.

- The workforce should not only be qualified, but compliant, but also the quality control systems applied in education should be reviewed.

- The number of start-up accelerator institutions, the number of technoparks and the number of credit risk capital funds should be increased.

- Work intensity should be increased in terms of new initiative. 
- Policies regarding the use of computers, internet access and expansion of use should be continued and fiber optic networks should be expanded and strengthened within this scope.

- The number of subscription types and secure servers should be increased and policies and strategies developed within this scope should be emphasized.

In the general ranking of the CISCO digital readiness index, Singapore, Luxembourg, USA, Denmark and Switzerland are in the first places. But Turkey Argentina, Belarus, Macedonia, situated in the same category with Azerbaijan. Accordingly, Turkey; basic needs, business and government investments, ease of doing business, human capital, start-up environment, technology adoption and technological infrastructure are generally not sufficient in digital transformation process. At this point, Turkey should give priority to policies that will be developed and implemented on the following issues and strategies: Safe drinking water and waste control, especially the promotion of foreign investments transferring foreign technology, ensuring the rule of law, overcoming economic stagnation, increasing the labor force participation rate in the medium and long term, reducing youth unemployment, harmonizing the workforce, start-up accelerator, technopark and credit risk Increasing the number of capital funds, computer usage, widespread access to and use of the internet, and expansion of fiber optic networks. 